\title{
Nauplius
}

The Journal OF The

Brazilian Crustacean Society

e-ISSN 2358-2936

www.scielo.br/nau www.crustacea.org.br

\section{Distribution of European and African species of genus Diaptomus (Copepoda: Calanoida: Diaptomidae): a track analysis}

\author{
Edinaldo Nelson dos Santos-Silva ${ }^{1}$ (iD) orcid.org/0000-0002-3340-4541 \\ Gerd-Oltmann Brandorff² ${ }^{2}$ orcid.org/0000-0001-8036-1399 \\ Mauro José Cavalcanti ${ }^{3}$
}
1 Laboratório de Plâncton-Coordenação de Biodiversidade, Instituto Nacional de Pesquisas da Amazônia. Manaus, Amazonas, Brazil
2 Georg-Gröning Strasse 29A, 28209 Bremen, Germany
GOB E-mail: gobrandorf@aol.com
3 Ecoinformatics Studio. Rio de Janeiro, Rio de Janeiro, Brazil
MJC E-mail: maurobio@gmail.com
ZOOBANK http://zoobank.org/urn:lsid:zoobank.org:pub:89450E0F-D765-46E9- B34B-EDDD4F1D3C82

\section{AbstRACt}

The distributional patterns of 13 species of Diaptomus Westwood, 1836 were analyzed using the panbiogeographical method of track analysis. Locality records were compiled from the literature and mapped for the construction of individual tracks for each species. These tracks were superimposed to find the generalized tracks. Four generalized tracks were found: (1) Siberia, Central Europe, and Iceland; (2) Northern Italy, southern France, central Spain, northern Algeria, and northern Morocco; (3) Southern France, central Spain, and northern Morocco; (4) Southern Italy, Sicily, and Albania. Five biogeographic nodes were found: (A) Southwestern Iberia, (B) Southeastern Iberia, (C) Central Iberia, (D) Cantabria, at the intersections of generalized tracks 2 and 3; and (E) Italian Peninsula Islands, at the intersection of generalized tracks 2 and 4 . The main massing of the species of Diaptomus studied is located in the Iberian peninsula, where six of the species do occur. A model based on the fragmentation and differentiation of already widespread ancestors during the late Mesozoic and early Cenozoic, related to the opening the North Atlantic Ocean and the formation of the Mediterranean Sea, is proposed as a most parsimonious explanation for the observed patterns of geographic vicariance.

CORRESPONDING AUTHOR Edinaldo Nelson dos Santos-Silva nelson@inpa.gov.br

SUBMITTED 26 April 2018 ACCEPTED 28 August 2018 PUBLISHED 03 December 2018

\section{Key Words}

Freshwater, copepods, distributional pattern, panbiogeography. 


\section{INTRODUCTION}

The genus Diaptomus Westwood, 1836 (Calanoida) comprises about 80 species of copepods characterized by the presence of a single eye spot and very elongated first antennae, exceeding body length. They occur in rivers and large freshwater lakes throughout the northern hemisphere.

The fossil record of Copepoda dates back to the late Carboniferous (Selden et al., 2010), but although there are already order-level phylogenies that corroborate the monophyletic status of Calanoida (Blanco-Bercial et al., 2011; Eyun, 2017; Khodami et al., 2017), no complete phylogeny of the Diaptomidae has been published to date. Thum (2004) provided a molecular phylogeny based on $18 \mathrm{~S}$ rDNA for selected North American genera of Diaptomidae. Mookkaiah and Ravichandran (2016) and Sivakumar et al. (2016) presented molecular phylogenies of several diatoptomid species, including some of those mentioned in the present study. Albeit still limited, these phylogenetic hypotheses offer a useful framework for the analysis of the evolution of calanoid copepods in relation to their distribution over geographic space.

Because of their small size, mode of reproduction, and dormant stages resistant to desiccation, copepod species have been believed to possess cosmopolitan distributions as a consequence of high rates of passive dispersal by winds and animal vectors, especially waterfowl and migratory birds (Maguire, 1963). This has led to speculation about 'colonization waves' (Boxshall and Jaume, 2000), 'glacial refugia' (Marrone et al.,2017), and other dispersalist narratives to explain the biogeography of copepods. However, empirical evidence has not supported the cosmopolitanism of copepods, suggesting instead that these crustaceans have in fact limited dispersal rates and display geographical distribution patterns with considerable degrees of endemism (Jenkins and Underwood, 1998; Bohonak and Jenkins, 2003; Boxshall and Defaye, 2008; Marrone et al., 2013). In the light of these findings, most recent studies of the geographical distribution of copepods have adopted a vicariant approach, under the paradigm of panbiogeography.

As first developed by Croizat $(1958 ; 1964)$, and later expanded and quantified by New Zealand researchers (Page, 1987; Craw, 1989; Henderson, 1989; Craw et al., 1999; Heads, 2012). Panbiogeography has been recognized as one of the main research programs in historical biogeography (Morrone and Crisci, 1995; Crisci, 2001; Crisci et al., 2003), including the biogeography of freshwater organisms (Bănărescu, 1990). The panbiogeographic method of track analysis consists of connecting the mapped locality records of different each taxa by means of lines of minimum distance, which defines the individual tracks, corresponding to the sector of geographical space where each taxon has evolved. When the individual tracks overlap for several groups, a generalized track is defined, suggesting a common history for the entire biota (Craw et al., 1999).

Track analysis of distributional patterns have been performed for selected groups of copepods: Jamieson (1998) analyzed the distribution of four species of Boeckella Guerne and Richard, 1889 in New Zealand, Menu-Marque et al. (2000) studied the distribution of this same genus in South America, and MercadoSalas et al. (2012) studied the distribution of the American species of Eucyclops Claus, 1893, using panbiogeographic methods. However, so far the panbiogeographic method has not been applied to analyze the distribution patterns of the widespread genus Diaptomus. Marrone et al. (2017) studied the distribution of Western Palearctic Diaptomidae using a macroecological approach which took into account current and historical (paleoclimatic) factors.

In this paper, the geographic distributions of 13 species of Diaptomus occurring in Europe and northern Africa were mapped and analyzed using the panbiogeographic method of track analysis, with the aim of finding common distribution patterns and attempting to correlate these patterns with vicariant events related to the tectonic history of the region.

\section{Materials and Methods}

Geographic distribution data for the species included in this study were compiled from the relevant literature and stored in an electronic spreadsheet in angular degrees format. A total of 395 occurrence records were obtained for all 13 European and African species of Diaptomus (Tab. 1). 
Table 1. Species of Diaptomus included in this study and number of occurrence records and respectives references for each one.

\begin{tabular}{|c|c|c|}
\hline Species & Number of records & References \\
\hline D. barabinensis Stepanova, 2008 & 1 & Stepanova (2008) \\
\hline D. castor (Jurine, 1820) & 133 & $\begin{array}{l}\text { Jurine (1820); Poppe (1889); Scott (1892); Barras (1900); Hartwig (1901); Scott (1902); Graeter } \\
\text { (1903); Wolf (1903); Wolf (1905); Norman and Scott (1906); Scott (1906); Gjorgjevic (1908); } \\
\text { Van Breemen (1908); Loppens (1908); Klausener (1908); Norman and Brady (1909); Schauß } \\
\text { (1911); Cepèdé (1911); Hartmann (1915); Farwick (1915a); Farwick (1915b); Stephensen (1917); } \\
\text { Haberbosch (1920); Roy (1922); Roy (1927); Roy (1931); Kiefer (1938); Gurney (1940); Herbst } \\
\text { (1951); Smyly (1958); Kiefer and Einsle (1963); Wawrik (1966); Grainger (1966); Röben (1970); } \\
\text { Amoros and Juget (1970); Amoros (1973a); Amoros (1973b) Amoros and Fanget (1973); Milad } \\
\text { (1974); Hebert and Hann (1986); Preston et al. (1989); Garcia-Gil et al. (1992); Blackstock et al. } \\
\text { (1993); Alonso (1998); Reynolds and Marnell (1999); Scher et al. (2000); Flößner et al. (2002); } \\
\text { Illyova and Kubicek (2002); Rundle et al. (2002); Moreira (2005); Marques et al. (2008); Sukop } \\
\text { (2008); Demeter and Marrone (2009); Maillet (2010); Traykov et al. (2011); Marrone et al. (2013); } \\
\text { Brüsin et al. (2016); Novichkova (2016) }\end{array}$ \\
\hline D. castaneti Burckhardt, 1920 & 24 & $\begin{array}{l}\text { Burckhard (1920); Roy (1931); Miracle (1978), Armengol (1978); Ramdani (1986); Vega et al. } \\
\text { (1992); Alonso (1998); Winder et al. (2001); Bouzidi et al. (2010); Miliani et al. (2014) }\end{array}$ \\
\hline D. charini Siewerth, 1928 & 1 & Siewerth (1928) \\
\hline D. cyaneus Gurney, 1909 & 136 & $\begin{array}{l}\text { Gurney (1909); Roy (1927); Pesta (1938); Pirocchi (1947); Kiefer (1955); Kiefer (1956); Aguesse } \\
\text { (1957); Marazanof (1963); Stella et al. (1972); Miracle (1978); Cruz-Pizarro (1983); Cruz-Pizarro } \\
\text { (1984); Ramdani (1986); Alonso (1987); Ramdani et al. (1989); Francisco and Rey (1994); Medina- } \\
\text { Sanchez et al. (1999); Rabet (1999); Brancelj and Gorjanc (1999); Barea-Arco et al. (2001); Inypsa } \\
\text { (2001); Ramdani et al. (2001); Samraoui (2002); Bouhbouh (2002); Guisande et al. (2003); Mura } \\
\text { and Brecciaroli (2003); Ventura (2004); Marrone and Naselli-Flores (2004), Pipan (2005); Rabet } \\
\text { et al.( 2005); Serrano and Fahd (2005); Catalan et al. (2006); Alonso and Garcia-de-Lomas (2009); } \\
\text { Bouzidi et al. (2010); Hamaidi et al. (2010); Sahuquillo and Miracle (2010); Garcia-Jurado et al. } \\
\text { (2011); Alfonso and Belmonte (2011); Parco Nazionale del Gargano (2012); Garcia-Jurado et al. } \\
\text { (2012); Alfonso and Belmonte (2013); Marrone et al. (2013); Alfonso et al. (2014); Miliani et al. } \\
\text { (2014); Riserva Naturale Capo Gallo (2015) }\end{array}$ \\
\hline D. falsomirus Kiefer, 1972 & 5 & $\begin{array}{l}\text { Mann (1940); Kiefer (1938); Kiefer (1972); Naidenow (1964); (Kiefer, 1972), Kiefer (1972); } \\
\text { Samchyshyna (2005) }\end{array}$ \\
\hline D. glacialis Lilljeborg, 1889 & 38 & $\begin{array}{l}\text { Lilljeborg (1889) in Guerne and Richard (1889b); Guerne and Richard (1892); Zykoff (1905); } \\
\text { Reed (1962); Tash and Armitage (1967); Tash (1971); Halbach and Fletchner (1976); Landvirkjun } \\
\text { (1976); Adalsteinsson (1979); Stross et al. (1980); Flechtner et al. (1982); Hebert and Hann (1986); } \\
\text { Malmquist et al. (2001); Jónasson (2002); Malmquist et al. (2003); Abramova (2003); Malmquist } \\
\text { (2005); Abramova and Tuschling (2005); Stepanova (2008); Anastasia et al. (2009); Bogdanova (2009); } \\
\text { Adalsteinsson (2011); Gruzdev (2014); Novichkova and Chertoprud (2015); Vinarski et al. (2015) }\end{array}$ \\
\hline D. kenitraensis Kiefer, 1926 & 10 & $\begin{array}{l}\text { Kiefer (1926); Kiefer (1928); Armengol (1976); Alonso (1998); Caramujo and Boavida (2010); } \\
\text { Marrone et al. (2013) }\end{array}$ \\
\hline D. kostromanus Kiefer, 1972 & 2 & Smirnov (1929); Kiefer (1972) \\
\hline $\begin{array}{l}\text { D. mirus Lilljeborg in Guerne } \\
\text { and Richard, } 1889\end{array}$ & 10 & $\begin{array}{l}\text { Lilljeborg (1889) in Guerne and Richard (1889a); Kiefer (1972); Nevsky (2006); Stepanova (2008); } \\
\text { Yevdokimov and Yermokhin (2009); Semyonova and Aleksyuk (2010); Vizer et al. (2013); Nefedov } \\
\text { (2013) }\end{array}$ \\
\hline D. rostripes Herbst, 1955 & 11 & Herbst (1955); Scher et al. (2000); Novichkova et al. (2014) \\
\hline D. serbicus Gjorgjweic, 1907 & 23 & $\begin{array}{l}\text { Chichkoff (1908); Gjorgjevic (1908); Charin (1927); Kiefer (1938); Stella (1964); Damian-Georgescu } \\
\text { (1966); Stella and Margaritora (1968); Kiefer (1972); Marrone et al. (2010); Alfonso and Belmonte } \\
\text { (2011); Marrone et al. (2013) }\end{array}$ \\
\hline D. zografi Kortchagin, 1887 & 1 & Kortschagin (1887) \\
\hline
\end{tabular}

Distribution maps for each species were created by means of the DIVA-GIS Geographic Information System (Hijmans et al., 2001; www.diva-gis.org). A Natural Earth (www.naturalearthdata.com) image at 1:50 million-scale was used as background layer for all maps. Individual tracks were constructed for each species by connecting their localities of occurrence with minimum spanning trees using the Croizat software (Cavalcanti, 2009). Generalized tracks were determined from the areas of overlap of individual tracks using the MartiTracks program (Echeverría-Londoño and Miranda-Esquivel, 2011). Biogeographic nodes 
(Heads, 2004) were determined at the intersection of two or more generalized tracks. The main massings (geographic concentrations of diversity) were assessed by counting the numbers of species in each cell of a 1 $\mathrm{x} 1$ degree grid using DIVA-GIS.

\section{Results AND Discussion}

The species studied and the number of occurrence records obtained for each are listed in Table 1. Distribution maps and individual tracks for each species are presented in Figures 1-10.

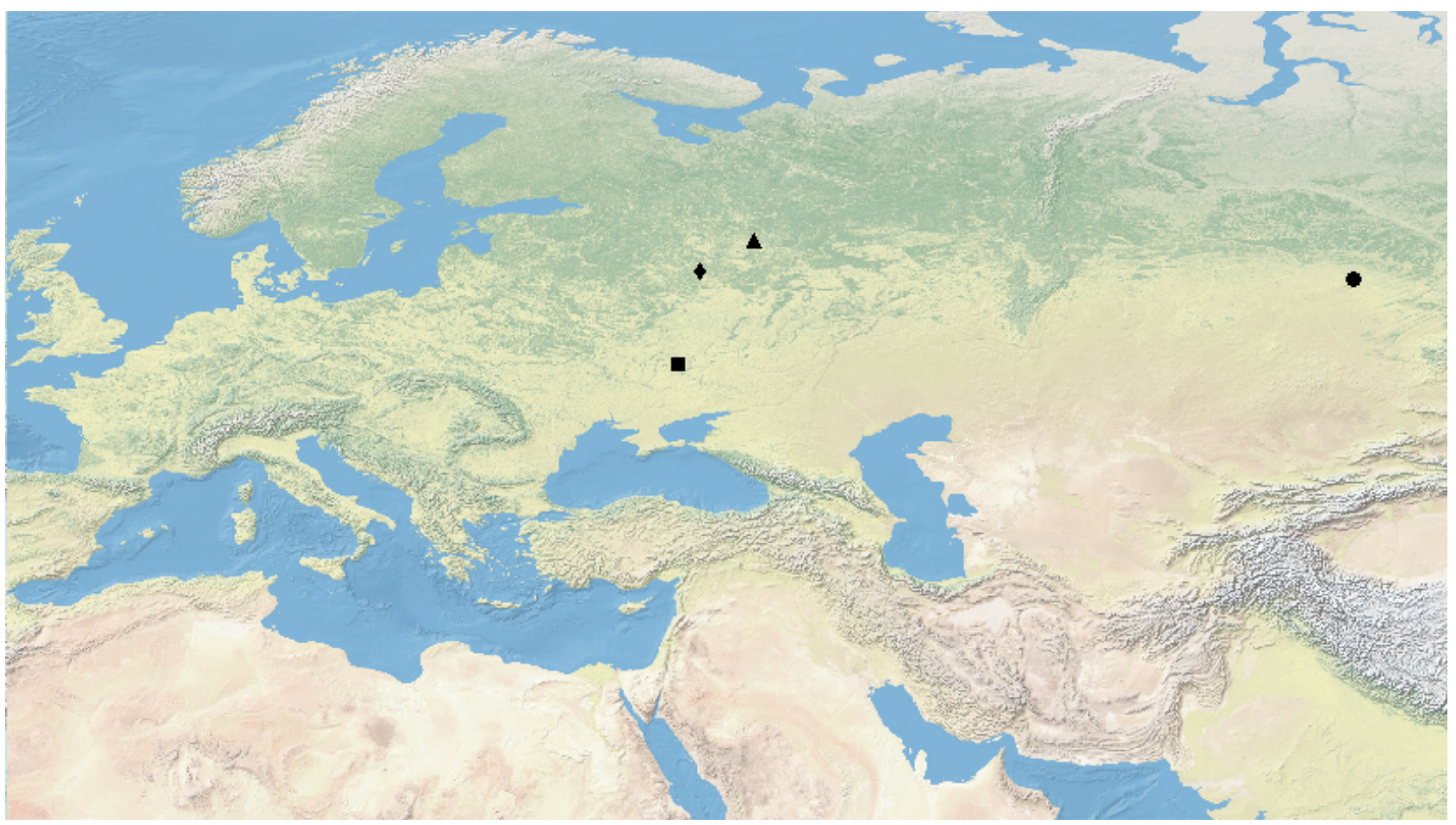

Figure 1. Distribution map of Diaptomus barabinensis $(\bullet)$, D. charini $(\boldsymbol{\bullet})$, D. kostromanus $(\boldsymbol{\Delta})$, and D. zografi $(\bullet)$.

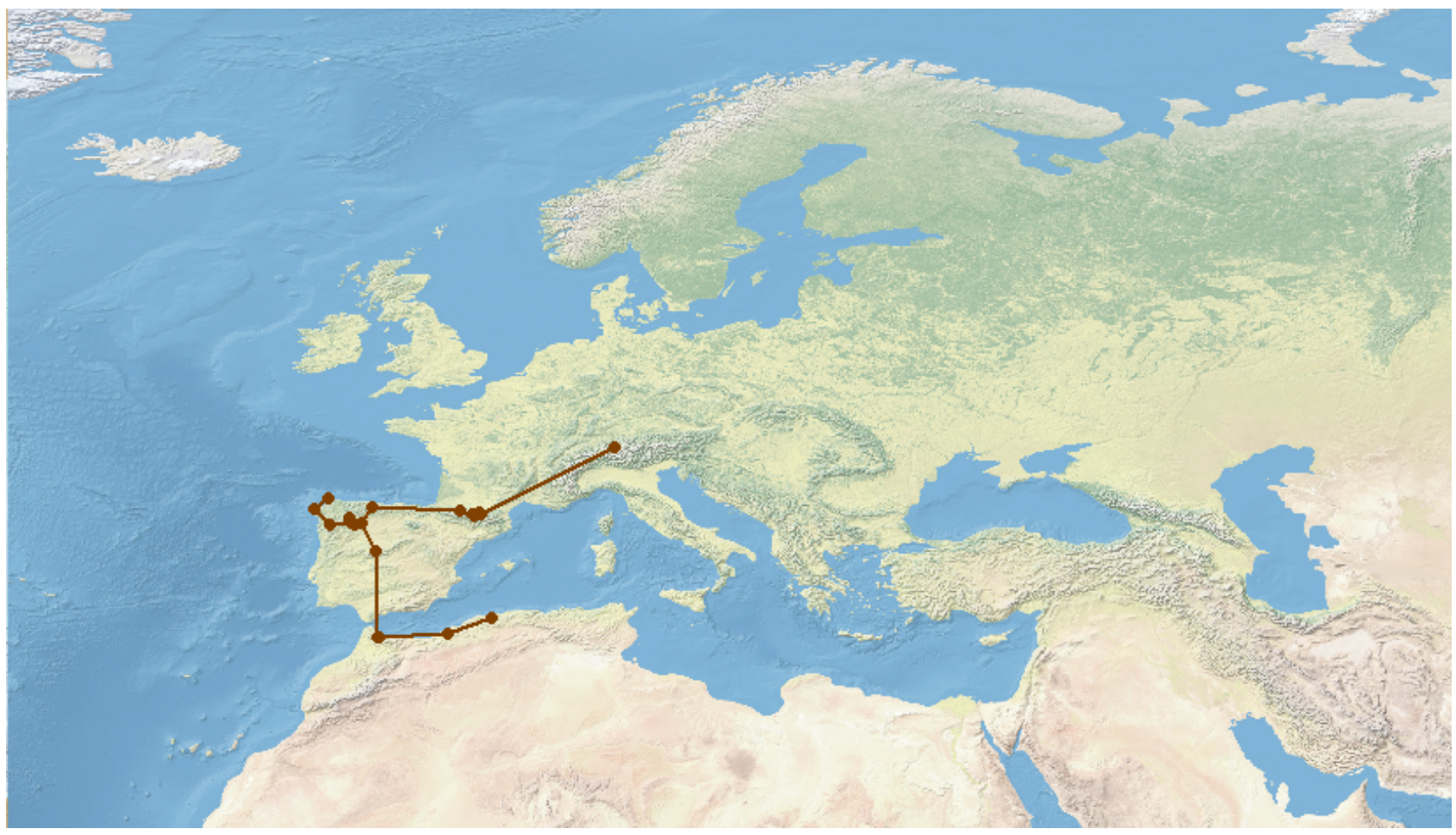

Figure 2. Individual track of Diaptomus castaneti. 


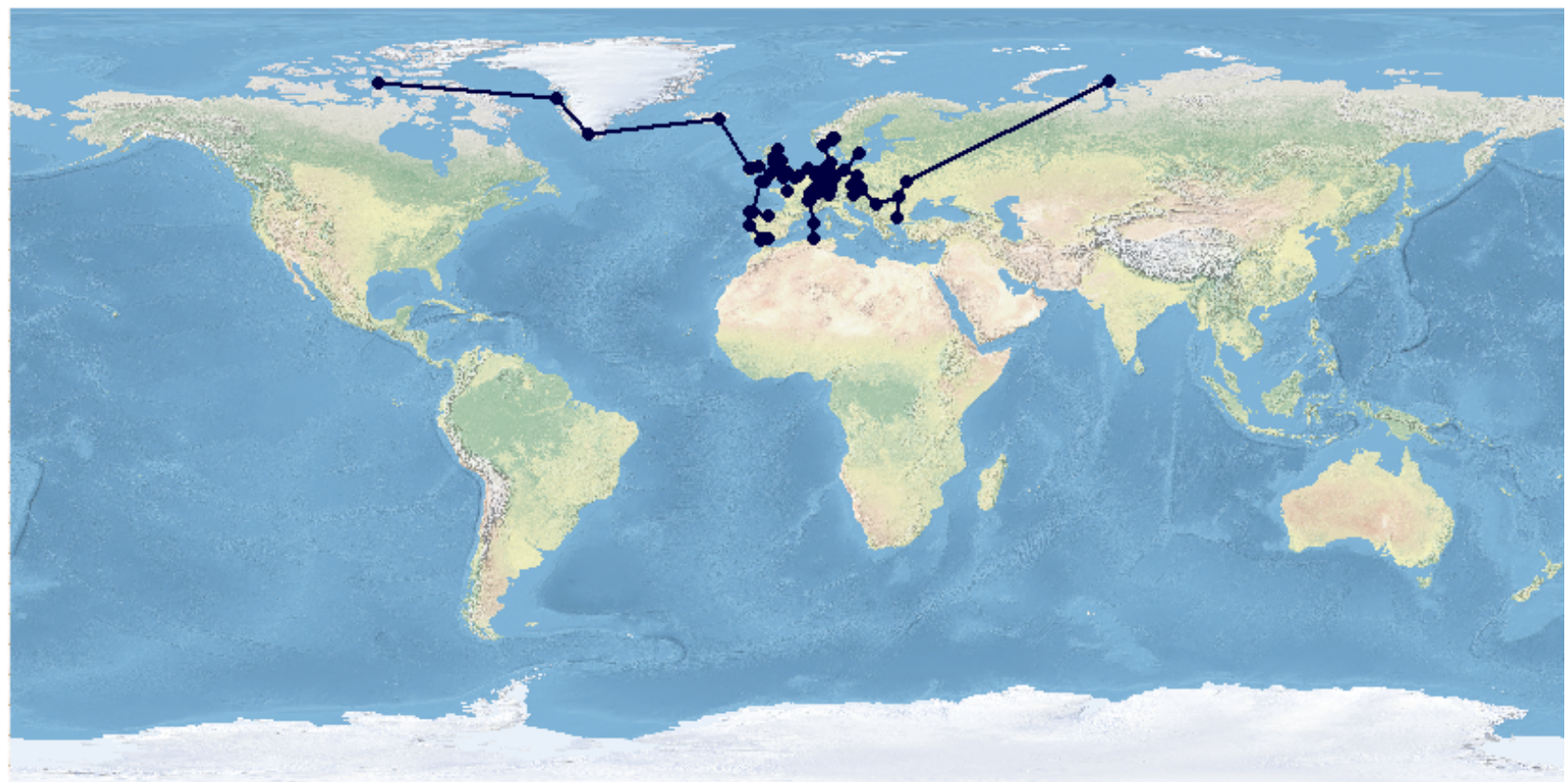

Figure 3. Individual track of Diaptomus castor

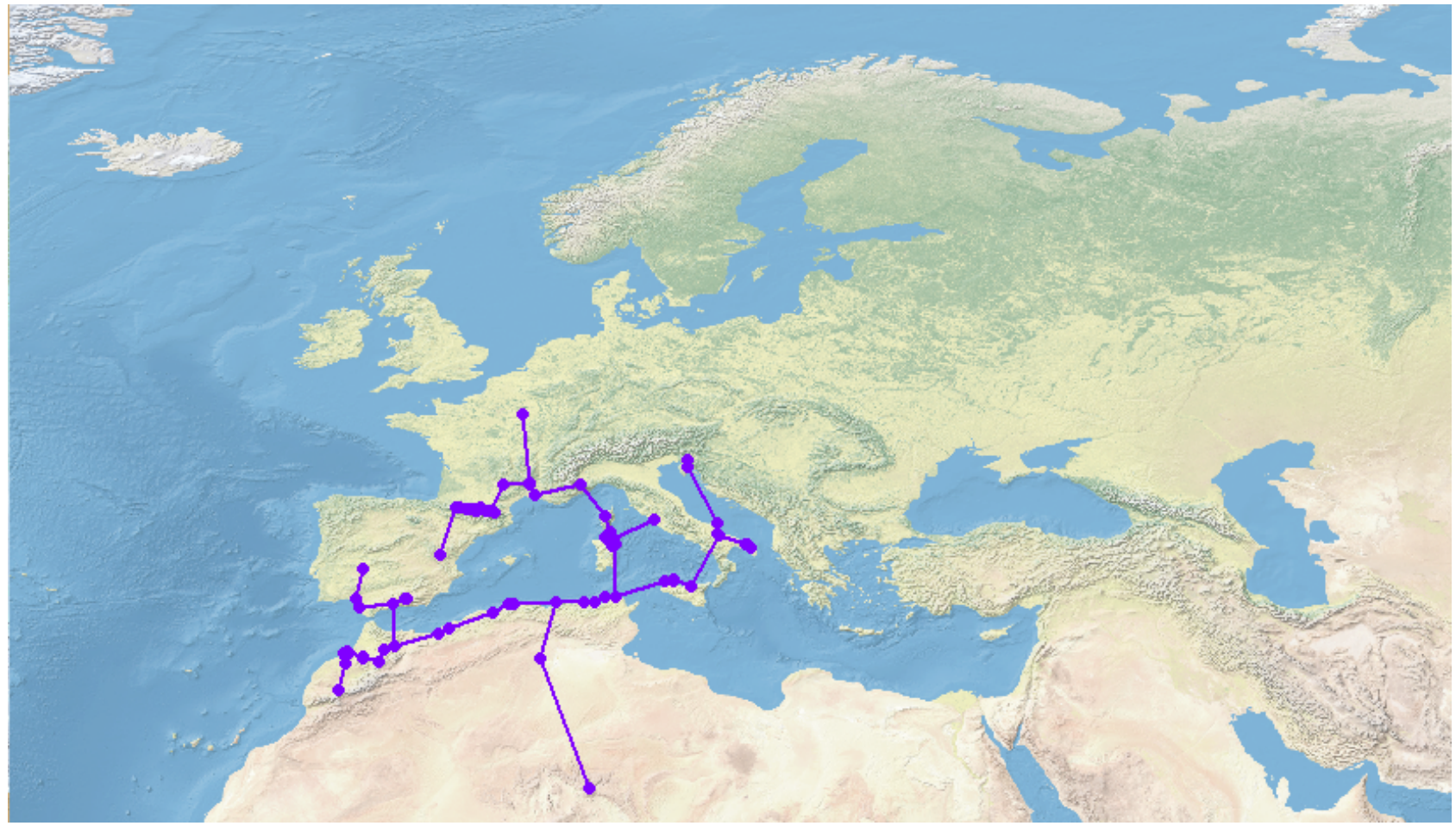

Figure 4. Individual track of Diaptomus cyaneus. 


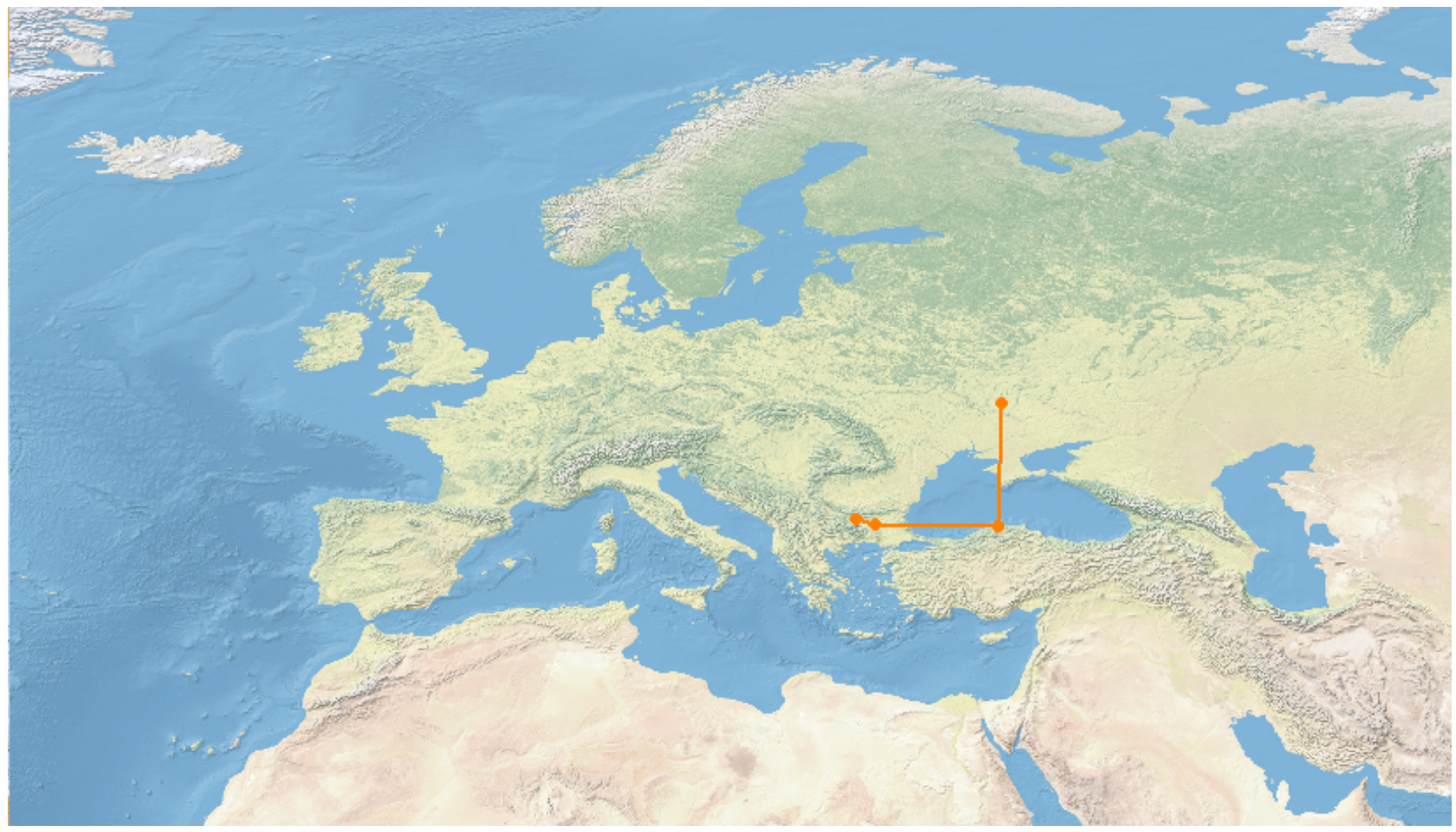

Figure 5. Individual track of Diaptomus falsomirus.

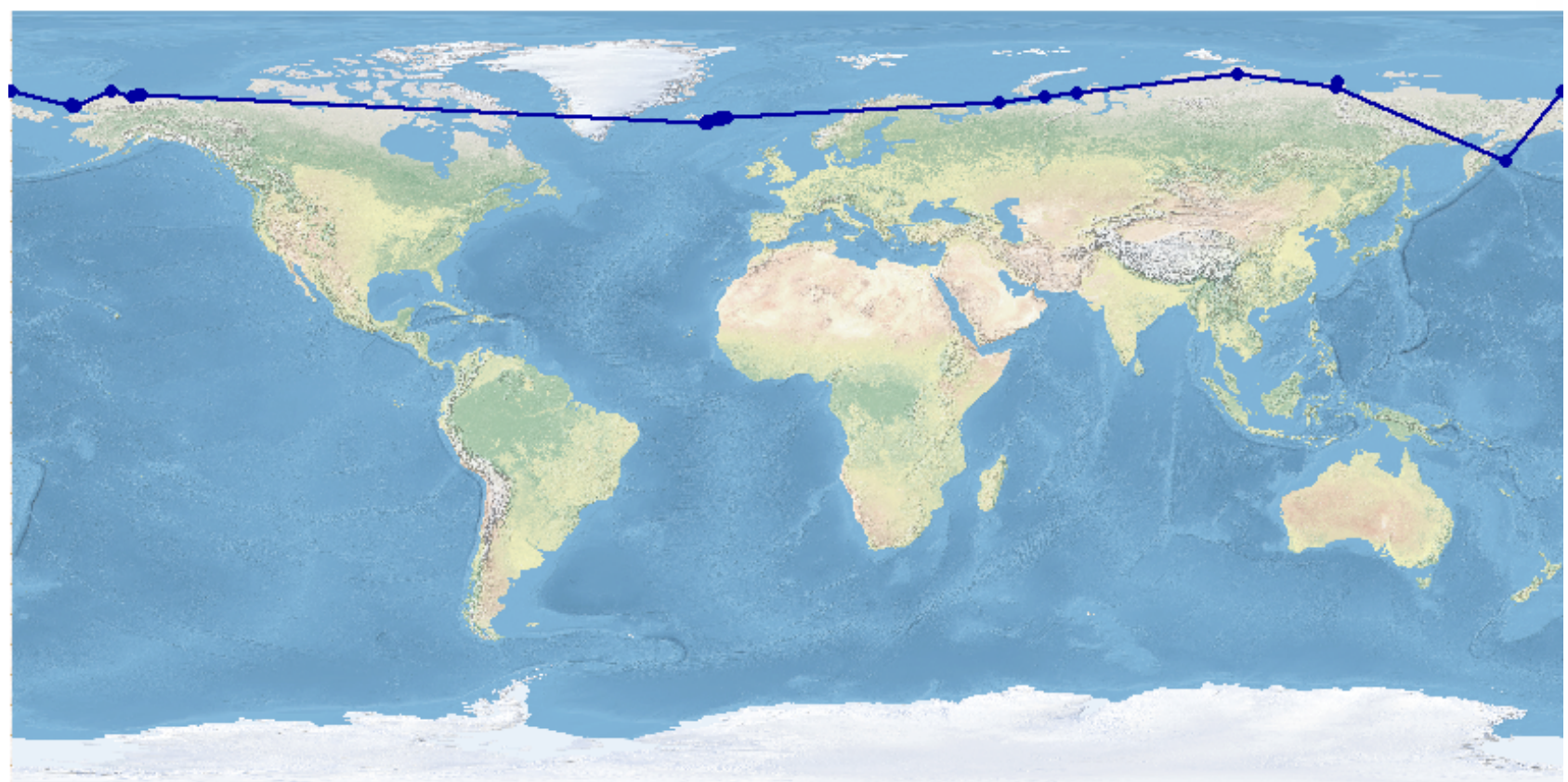

Figure 6. Individual track of Diaptomus glacialis. 


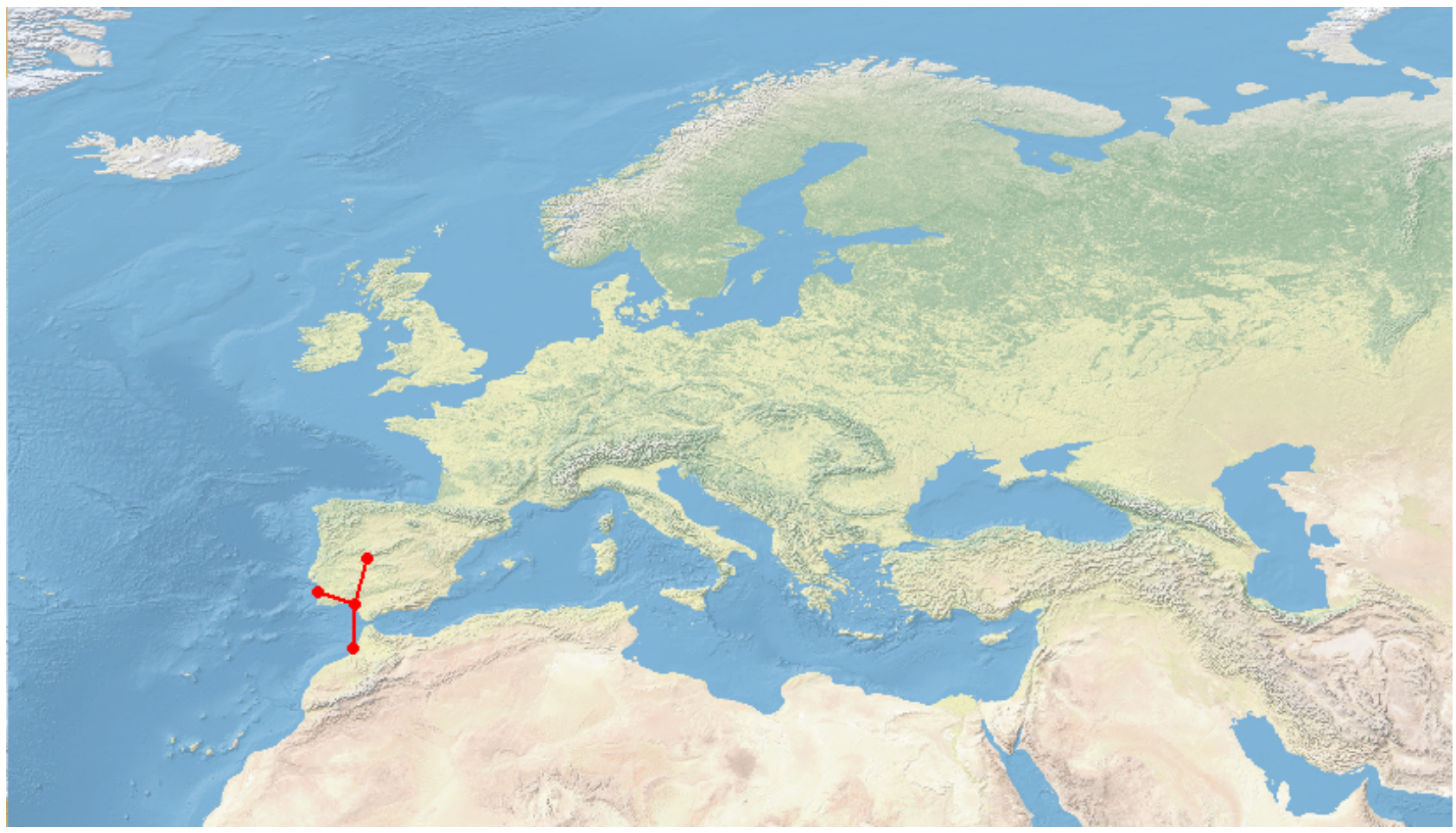

Figure 7. Individual track of Diaptomus kenitraensis.

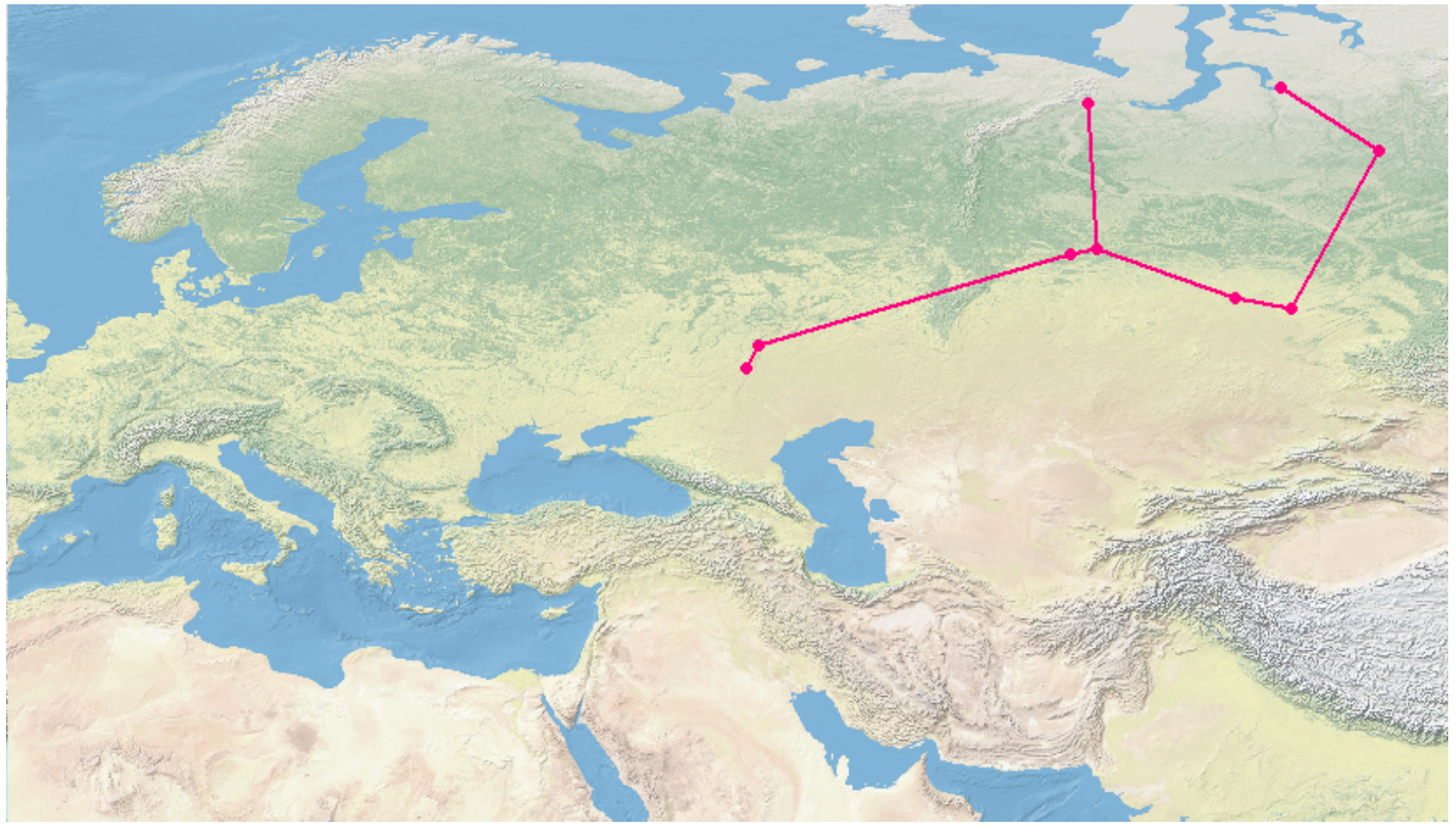

Figure 8. Individual track of Diaptomus mirus. 


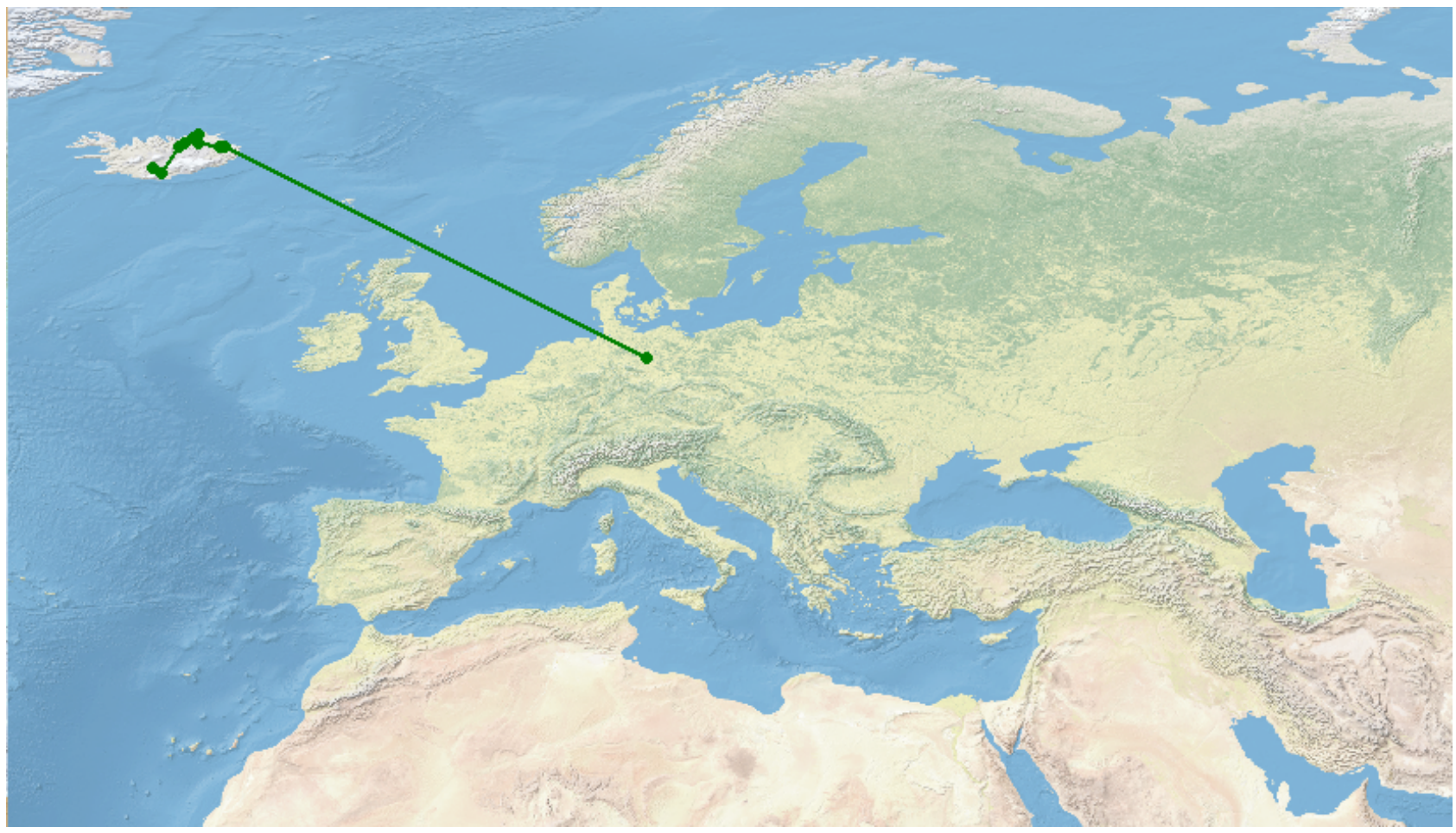

Figure 9. Individual track of Diaptomus rostripes.

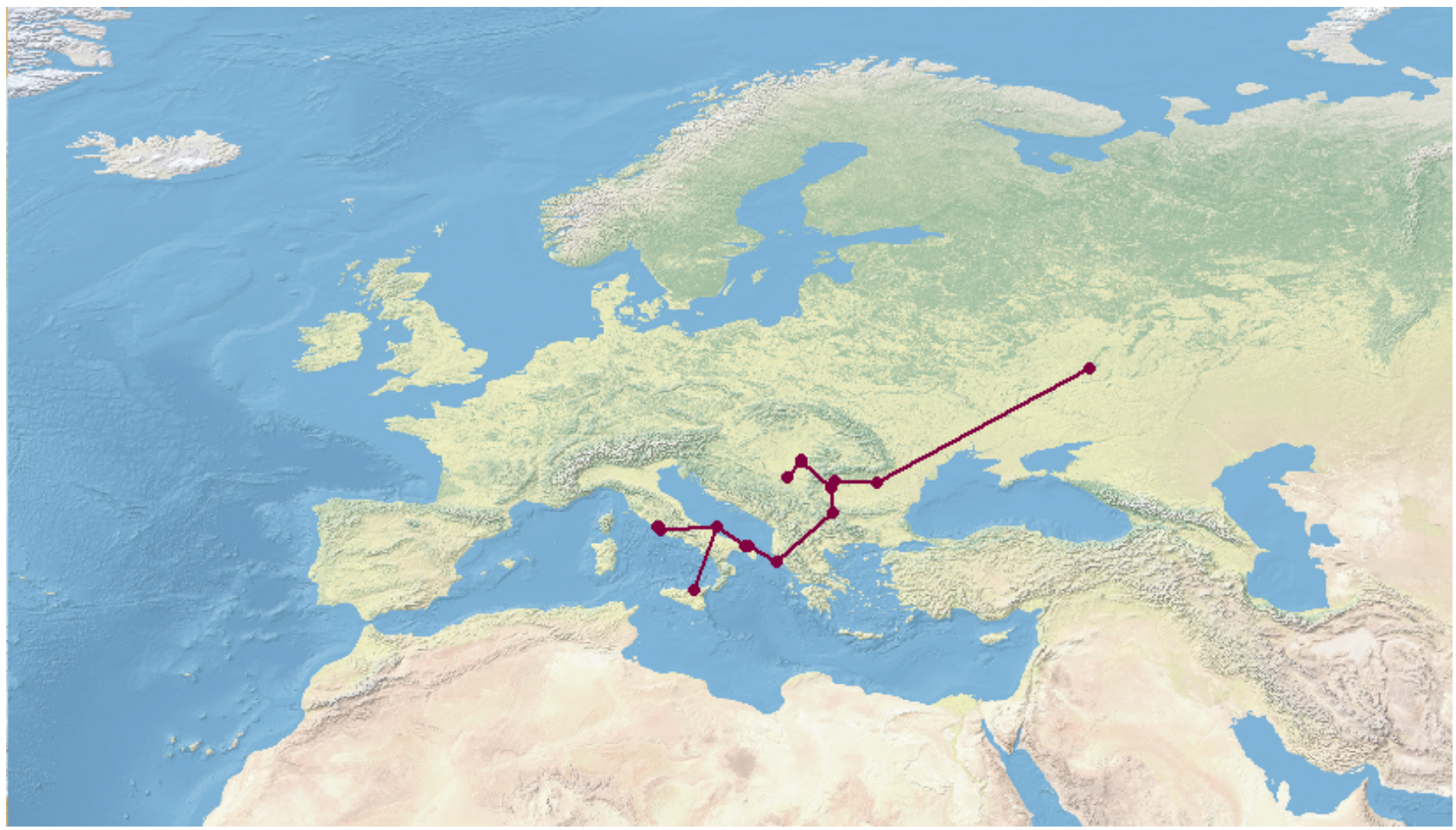

Figure 10. Individual track of Diaptomus serbicus. 
Of the 13 species of Diaptomus included in this study, five (D. barabinensis Stepanova, 2008, D. charini Siewerth 1928, D. falsomirus Kiefer, 1972, D. kostromanus Kiefer, 1972, D. zografi Korchagin, 1887) had fewer than ten occurrence records.

Four generalized tracks were identified, based on the coincidence of the individual tracks for each species (Fig. 11). These tracks are defined as follows: (1) Siberia, Central Europe, and Iceland (including Diaptomus glacialis Lilljeborg, 1889, D. rostripes Herbst, 1955 and D. castor (Jurine, 1820)); (2) Northern Italy, southern France, central Spain, northern Algeria, and northern Morocco (including D. cyaneus Gurney, 1909, D. castor, and D. castaneti Burckhardt, 1920); (3) Southern France, central Spain, and northern Morocco (including D. kenitraensis Kiefer, 1926, and D. castor); (4) Southern Italy, Sicily, and Albania (including D. serbicus Gjorgjweic, 1907, and D. castor).

Five biogeographic nodes were determined: (A) Southwestern Iberia, (B) Southeastern Iberia, (C) Central Iberia, (D) Cantabria, at the intersections of generalized tracks 2 and 3; and (E) Italian Peninsula Islands, at the intersection of generalized tracks 2 and 4 (Fig. 11).
Diaptomus castor is the most widespread species, occurring from Iceland to northwestern Africa, followed by $D$. cyaneus which occurs from Cantabria to northwest Africa. The main massing of the species of Diaptomus included in the present study (Fig. 12) is located in Iberia, where six of the species occur.

The scattered highly localized endemics of northern Eurasia (D. barabinensis, D. charini, D. kostromanus, D. zografi) stands in contrast to the wider range of other species. The distribution of D. falsomirus (Fig. 5) appears to be centered on the Black Sea basin and is also allopatric to all other species (which are all centered west or north). Likewise, the distribution of D. mirus Lilljeborg in Guerne and Richard, 1889 is disjunct in north and central Eurasia (Fig. 8).

The distribution patterns of the species of Diaptomus included in the present study, as revealed by track analysis, suggest that two major geotectonic events had a role in shaping the evolution of these species, namely the formation of the Mediterranean Sea and the formation of Iceland.

The Mediterranean Sea has a very complex geological history, comprising not only the formation of the basin by the convergence of the African and

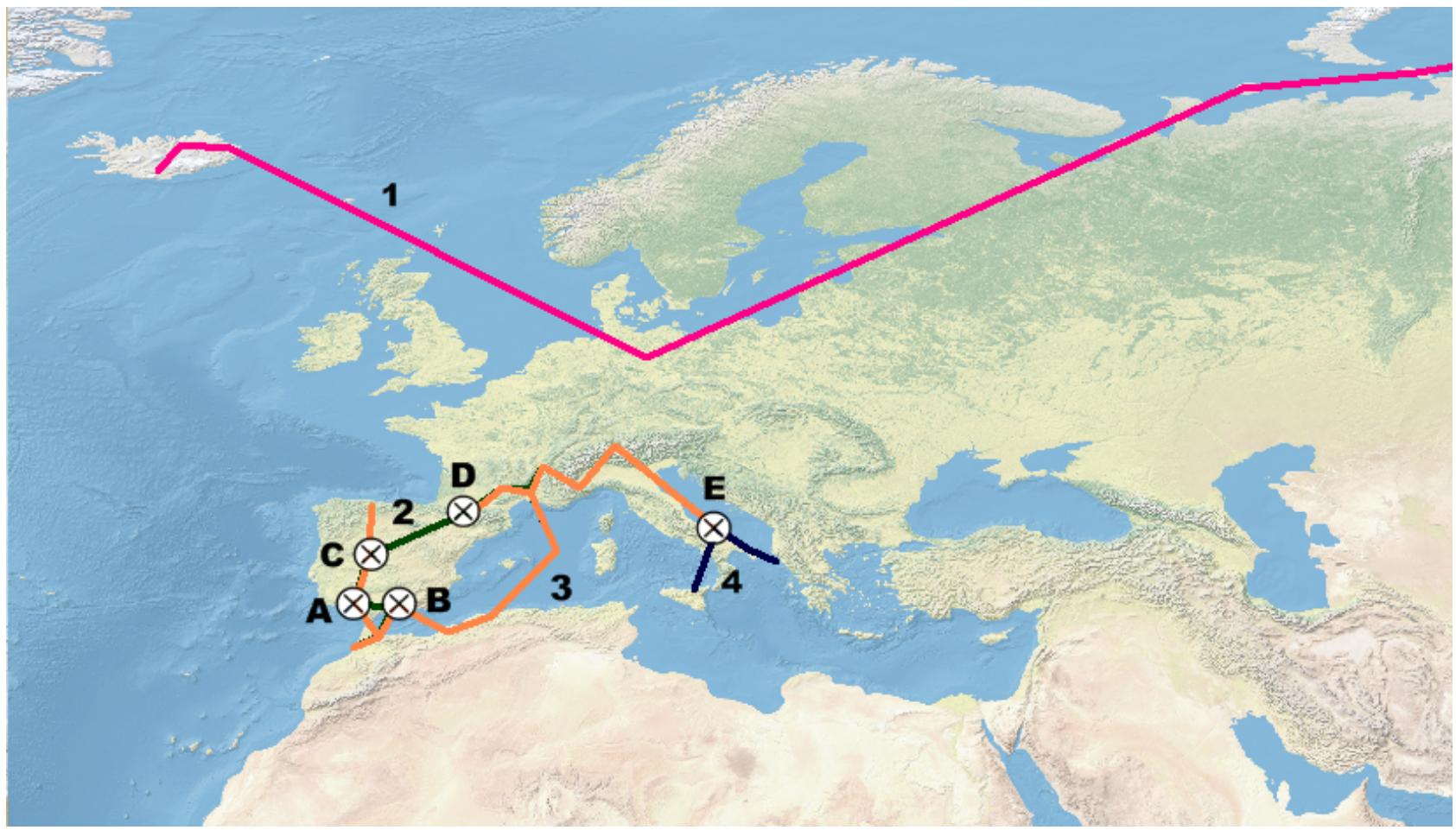

Figure 11. Generalized tracks and nodes of the species of Diaptomus included in this study. (1) Siberia-Central Europe-Iceland track;

(2) Northern Italy-southern France-central Spain-northern Africa track; (3) Southern France-central Spain-northern Africa track;

(4) Southern Italy-Sicily- Albania track. (A) Southwestern Iberia node, (B) Southeastern Iberia node, (C) Central Iberia node, (D) Cantabria node; (E) Italian Peninsula Islands node. 


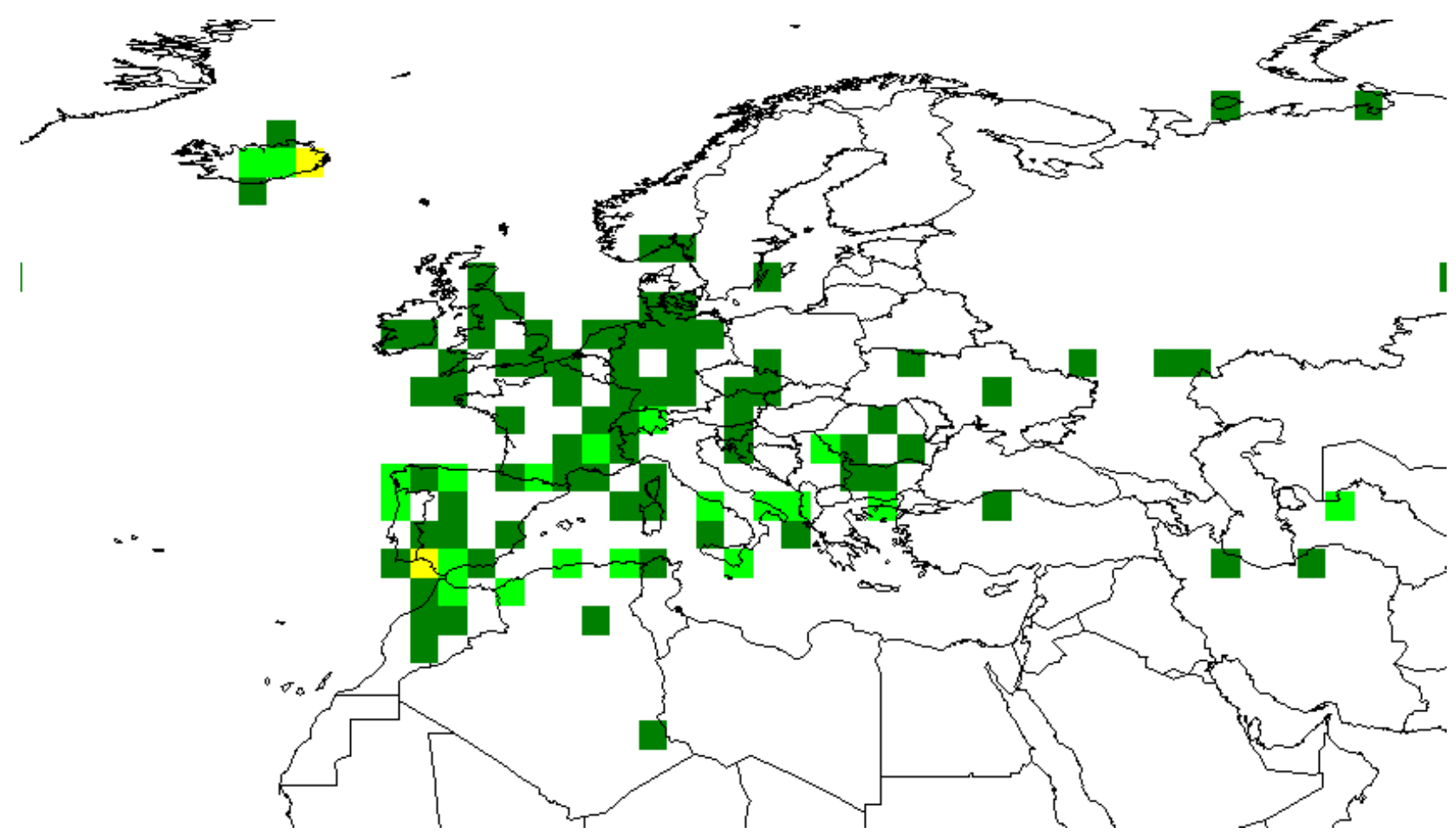

Figure 12. Centers of diversity (main massings) of the species of Diaptomus included in this study. Yellow: three species, light green: two species, dark green: one species.

Eurasian plates during the Late Triassic and Early Jurassic, but also several cycles of partial or complete desiccation during the Messinian age of the Late Miocene (Garcia-Castellanos and Villaseñor, 2011). This may explain the biogeographic nodes centered in the southern Iberian peninsula and around the Strait of Gibraltar, a region that marks the sector of geographic space where biotas have fragmented and coalesced during such cycles. These patterns are also corroborated by the molecular phylogenetic tree of Mookkaiah and Ravichandran (2016), where D. mirus, D. cyaneus and D. kenitraensis, D. castor form separate clades which are consistent with the observed patterns of geographic vicariance. These branching sequences are interpreted here not as separate dispersal events but as the 'sequence of differentiation in an already widespread ancestor' (Heads, 2009).

Generalized track 1, formed by the distributions of $D$. castor, D. glacialis, and D. rostripes is component of a standard track first identified by Croizat (1958) which includes many more elements of the boreal biota. These three species are recorded from Iceland (with just one record for D. castor in the southwestern part of the island).
Iceland lies on the divergent boundary between the North American and Eurasian tectonic plates, as well as above a hotspot, the so-called Iceland plume, which is believed to have formed the island itself (Mjelde et al., 2008; Torsvik et al., 2015). Iceland is a relatively young island, first appearing over the ocean surface about 16 Myr ago (Foulger, 2006), and this might suggest long-distance dispersal as an explanation for the presence of these three species of Diaptomus on Iceland. However, an alternative explanation which does not rule out vicariance is possible. First, the plume model is debatable (Heads, 2009): it may be that Iceland is not even underlain by a lower mantle plume, and volcanic activity in the island could result from processes restricted to the upper mantle and related to plate tectonics (Foulger and Anderson, 2005; Foulger and Natland, 2003; Foulger 2010; Heads, 2009). Second, island age cannot be taken as an absolute criterion for dating the age of taxa (Heads, 2009), as old taxa can survive as metapopulations on ephemeral islands of younger age formed at plate margins and fissures and now submerged (for example, on the Faroe-Rockall Plateau). 
The biogeographic nodes cluster to the central and western Mediterranean. Nodes A and B lie on the edge of the western Mediterranean and may be related to the reestablishment of the connection between this basin and the Atlantic Ocean through the Strait of Gibraltar by the Zanclean flood around 5.3 Myr ago (Garcia-Castellanos et al., 2009). One node (D) is at the Pyrenees so that might suggest that the tectonic compression of the Pyrenees and its age might be a factor in differentiation at this node. The Pyrenean chain achieved its present configuration due to the collision between the microcontinent Iberia and the southwestern part of the European Plate (i.e., Southern France), that approached in the onset of the Upper Cretaceous (Albian/Cenomanian), about $100 \mathrm{Myr}$ ago, and collided during the Paleogene (Eocene/ Oligocene), around 55 to $25 \mathrm{Myr}$ ago (Choukroune, 1992). The region is bounded by major faults, and such orogenic zones are known to be associated with major biological disjunctions (Croizat, 1958; 1964; Heads, 1989). The node in Italy (E) seems to represent a boundary for distributions further west and likewise the tectonic activity in the region is pertinent to explain biological disjunction patterns in this region. This node is associated with the Apulian/Adriatic Plate, a tectonic microplate that separated from the African Plate during the Mesozoic, and generalized track 4 coincides with the Calabrian arc which marks the microplate boundary (Devoti et al., 2002).

Recently, Marrone et al. (2017) presented an analysis of the distribution patterns of diaptomid copepods in the Palearctic, which these authors explained on the basis of effects of recent (i.e., of Holocene age) climatic changes and post-glacial 'recolonizations' from putative 'refugia' in Western Europe. But this interpretation is not supported here, and instead the observed distribution patterns are explained in the light of much older geotectonic events and involved no long-distance dispersal over putative 'barriers'.

Vicariance promoted by geotectonic events extending back to the Mesozoic has played a most important role in shaping the distribution of the species of Diaptomus included in this study. This process give rise to analyzable patterns affecting whole biotas (the generalized tracks) and best explains the biogeographic connections observed between the copepod fauna of continental Europe and Iceland, as well as of the Iberian and Italian peninsulas. A model based on the fragmentation and differentiation of already widespread ancestors during the late Mesozoic and early Cenozoic, related to the opening the North Atlantic Ocean and the formation of the Mediterranean Sea offers a most parsimonious explanation for these patterns.

\section{ACKNOWLEDGEMENTS}

We thank John Grehan and Michael Heads for helpful comments and useful suggestions that contributed to improvements in the manuscript.

\section{References}

Abramova, E.N. and Tuschling, K. 2005. A 12-year study of the seasonal and interannual dynamics of mesozooplankton in the Laptev Sea: Significance of salinity regime and life cycle patterns. Global and Planetary Change, 48: 141-164.

Abramova, E.N. 2003. Species composition, ecology, population structure and seasonal dynamics of zooplankton from tundra water basins in the Lena Delta. p. 96-100. In: Russian. German Cooperation SYSTEM LAPTEV SEA: The Expedition LENA 2002. Berichte zur Polar- und Meeresforschung, 466 p.

Adalsteinsson, H. 1979. Zooplankton and its relation to available food in Lake Mývatn. Oikos, 32: 162-194.

Adalsteinsson, H. 2011. Fisktannsóknir i Drauneyjalóni 2011. Landsvirkjun, 12p. LV-2011-114.

Aguesse, P.-C. 1957. Complément à l'inventaire de la faune invertébrée des eaux camarguaises. La Terre et la Vie, 104: 241-252.

Alfonso, G. and Belmonte, G. 2011. Calanoida (Crustacea Copepoda) from the inland waters of Apulia (south-eastern Italy). Journal of Limnology, 70: 57-68.

Alfonso. G. and Belmonte, G. 2013. Neolovenula alluaudi (Guerne and Richard, 1890) (Calanoida: Diaptomidae: Paradiaptominae): first record in Italy and review of geographical distribution. Journal of Limnology, 72: 251-261.

Alfonso, G.; Russo, R. and Belmonte, G. 2014. First record of the Asian diaptomid Neodiaptomus schmackeri (Poppe \& Richard, 1892) (Crustacea: Copepoda: Calanoida) in Europe. Journal of Limnology, 73: 584-592.

Alonso, M. 1987. Ejemplos de Vicarianza en Comunidades de Crustaceos de Lagunas Esteparias. Limnetica, 3: 81-89.

Alonso, M. 1998. Las lagunas de la España Peninsular. Limnetica, 15: $1-176$.

Alonso, M. and Garcia-de-Lomas, J. 2009. Systematics and ecology of Linderiella baetica n. sp. (Crustacea, Branchiopoda, Anostraca, Chirocephalidae), a new species from southern Spain. Zoosystema, 31: 807-827.

Amoros, C. and Juget, J. 1970. Donnèes préliminaires sur la faune planctonique et benthique de deux étangs piscicoles de la Dombes (AIN). Annales de Limnologie, 6: 215-227. 
Amoros, C. 1973a. Évolution des populations de Cladocères et Copépodes dans trois etangs piscicoles de la Dombes. Annales de Limnologie, 9: 135-155.

Amoros, C. 1973b. Contribution A L'ecologie de Diaptomus castor (Jurine, 1820) (Crustacé, Copépode Dulçaquicole): Determinisme de L'eclosion des Oufs Latents. Bulletin Mensuel de la Société Linnéenne de Lyon, 9: 235-241.

Amoros, C. and Fanget, R. 1973. Le peuplement en Crustacés planctoniques de trois étangs piscicoles de la Dombes et son incidence sur l'alimentation naturelle de la carpe. Bulletin de la Société des Naturalistes et des Archéologues de l'Ain, 87:21-23.

Anastasia, A.; Abramova, E. and Shakurova, N. 2009. Structure of zooplankton communities of the southern part of the delta of the Lena river. "Scientific community of students of the XXI century. Natural science ". SibAK. Novosibirsk, H 34: 39-46. (Russian).

Armengol, J. 1976, Crustáceos acuáticos del Coto de Doñana. Oecologia aquatica, 2: 93-97.

Armengol, J. 1978. Zooplankton crustaceans in Spanish reservoirs. Verhandlungen der Internationalen Vereinigung für Theoretische und Angewandte Limnologie, 20: 1652-1656.

Bănărescu. P. 1990. Zoogeography of Fresh Waters. Volume 1: General Distribution and Dispersal of Freshwater Animals. Wiesbaden, Aula-Verlag, 511p.

Barea-Arco, J.; Pérez-Martínez, C. and Morales-Baquero, R. 2001. Evidence of a mutualistic relationship between an algal epibiont and its host, Daphnia pulicaria. Limnology and Oceanography, 46: 871-881.

Barras, S. 1900. Excursiones por Palencia. Anales de la Sociedad Española de Historia Natural, 29: 163-169.

Blackstock, T. H.; Duigan, C.A., Stevens, D.P. and Yeo, M.J.M. 1993. Vegetation zonation and invertebrate fauna in Pant-yllyn, an unusual seasonal lake in South Wales, UK. Aquatic Conservation: Marine and Freshwater Ecosystems, 3: 253-268.

Blanco-Bercial, L.; Bradford-Grieve, J. and Bucklin, A. 2011. Molecular phylogeny of the Calanoida (Crustacea: Copepoda). Molecular Phylogenetics and Evolution, 59: 103-113.

Bogdanova, E.N. 2009. Jamal zooplankton studies (zooplankton pool R. Kharasavey-Yakha, middle Jamal). Research Bulletin, 1: 9-18. (Russian)

Bohonak, A.J. and Jenkins, D.G. 2003. Ecological and evolutionary significance of dispersal by freshwater invertebrates. Ecology Letters, 6: 783-796.

Bouhbouh, S. 2002. Bio-écologie de Barbus callensis (Valencienne 1842 ) et Barbus fritschi (Günther 1874) au niveau du réservoir Allal El Fassi (Maroc). Dhar El Mehraz Fes, Morocco. Ph.D. Thesis. 168p. [Unpublished].

Bouzidi, M.A.; Amar, Y.; Attaoui, I.; Latrèche, A.; Benyahia, M.; Bouguenaya, N. and Meliani. H. 2010. Copépodes, Cladocères et Rotifères du lac Sidi M'hamed Benali (Algérie NordOccidentale), Géographie, Physique et Environment, 4: 69-85.

Boxshall, G.A. and Defaye, D. 2008. Global diversity of copepods (Crustacea: Copepoda) in freshwater. Hydrobiologia, 59: 195-207.

Boxshall, G.A. and Jaume, D. 2000. Making waves: the repeated colonization of fresh water by copepod crustaceans. Advances in Ecological Research, 31: 61-79.
Brancelj, A. and Gorjanc, N 1999. On the presence of Chirocephalus croaticus (Steuer, 1899) in an intermittent lake in SW Slovenia. Hydrobiologia, 412: 25-34.

Brüsin, M.; Svenson, P. A. and Hylander, S. 2016. Individual changes in zooplankton pigmentation in relation to ultraviolet radiation and predator cues. Limnology and Oceanography, 61: 1337-1344.

Burckhardt, G. 1920. Zooplankton aus spanischen Gebirgsseen. 1. Ein zoogeographisch wertvoller neuer Diaptomus. (Diaptomus castaneti n. sp). Revue d'Hydrologie, 1: 123-13.

Caramujo, M.J. and Boavida, M.J. 2010. Biological diversity of copepods and cladocerans in Mediterranean temporary ponds under periods of contrasting rainfall. Journal of Limnology, 69: 64-75.

Catalan, J.; Camarero, L.; Felip, M.; Pla, S.; Ventura, M.; Buchaca, T.; Bartumeus, F.; Mendoza, G.; Miró, A.; Casamayor, E. O.; Medina-Sánchez, J.M.; Bacardit, M.; Altuna, M.; Bartrons, M. and Quijano, M. D. 2006. High mountain lakes: extreme habitats and witnesses of environmental changes. Limnetica, 25: 551-584.

Cavalcanti, M.J. 2009. Croizat: a software package for quantitative analysis in Panbiogeography. Biogeografía, 4: 4-6.

Cepèdé, C. 1911. Materiaux pour la limnobiologie du nord de la France. 3me Note. Sur la présence de Diaptomus castor Jurine dans les mares des dunes de Wimereux-Ambleteuse et description de Gurleya richardi n. sp. microsporidie nouvelle parasite de ce copépode d'eau douce. Annales de Biologie Lacustre, 5: 27-32.

Charin, N. 1927: Some findings of Diaptomidae in temporary waters in Woronesch Gouvernment. Travaux de l'Institut des recherches scientifiques l'Universite Voroneje, 1: 34-40. (Russian).

Chichkoff, G. 1908. Materiali za izuchvane sladkovodnata fauna na B'lgariya. I Svobodni Copepoda. Contribution à l'étude des Copépodes d'eau douce de la Bulgarie. Annuaire de l'Université de Sofia, Faculté physico-mathématique, 3-4: 300-350 (Bulgarian).

Choukroune, P. 1992. Tectonic evolution of the Pyrenees. Annual Review of Earth and Planetary Science, 20: 143-158.

Craw, R.C. 1989. Quantitative panbiogeography: introduction to methods. New Zealand Journal of Zoology, 16: 485-494.

Craw, R.C.; Grehan, J.R. and Heads, M.J. 1999. Panbiogeography: Tracking the History of Life. New York, Oxford University Press. 229p.

Crisci, J.V. 2001. The voice of historical biogeography. Journal of Biogeography, 28: 157-168.

Crisci, J.V.; Katinas, L. and Posadas, P. 2003. Historical Biogeography: An Introduction. Cambridge, Harvard University Press, 264p.

Croizat, L. 1958. Panbiogeography. Vols. 1 and 2. Caracas, published by the author. $1731 \mathrm{p}$.

Croizat, L. 1964. Space, time, form: the biological synthesis. Caracas, published by the author. 881p.

Cruz-Pizarro, L. 1983. Reproductive activity of Mixodiaptomus laciniatus in a high mountain lake (La Caldera). Hydrobiologia, 107: 97-105.

Cruz-Pizarro, L. 1984. Morphological and biometrical considerations of 2 Diaptomids (Mixodiaptomus laciniatus, Diaptomus cyaneus) from a High Mountain Lake, La-Caldera, 
Granada, Spain (Copepoda, Calanoida). Crustaceana, 46: 225-240.

Damian-Georgescu, A. 1966. [Copepoda. Calanoida (Forme de apă dulce)]. [Book in Rumanian]. Bucharest, Academiei RSR (ed). 128p.

Demeter, L. and Marrone, F. 2009. Updated checklist and distribution of the inland-water calanoid copepods (Copepoda: Calanoida) of Romania. North-Western Journal of Zoology, 5: 370-378.

Devoti, R.; Ferraro, C.; Gueguen, E.; Lanotte, R.; Luceri, V.; Nardi, A.; Pacione, R.; Rutigliano, P.; Sciarretta, C. and Vespe, F. 2002. Geodetic control on recent tectonic movements in the central Mediterranean area. Tectonophysics, 346: 151-167.

Echeverría-Londoño, S. and Miranda-Esquivel, D.R. 2011. MartiTracks: a geometrical approach for identifying geographical patterns of distribution. PLoS ONE, 6: e18460.

Eyun, S.I. 2017. Phylogenomic analysis of Copepoda (Arthropoda, Crustacea) reveals unexpected similarities with earlier proposed morphological phylogenies. BMC Evolutionary Biology, 2017: 17-23.

Farwick, B. 1915a. Neuere Untersuchungen über die Verbreitung der freilebenden Copepoden am Niederrhein und ihre Biologie. Archiv für Naturgeschichte, 81: 7-27.

Farwick, B. 1915b. Zur Verbreitung der Cyclops nanus Sars diaphanoides Graeter und des Cyclops languidus Sars. Archiv für Naturgeschichte, 81: 158-160.

Flechtner, G.; Gardarsson, A.; Gislason, G.M. and Halbach, U. 1982. Ökologische Untersuchungen in Thjorsarver, ZentralIsland. Natur und Museum, 112: 49-61.

Flößner, D.; Hartmann, G. and Reinecke, W. 2002. Zur Kenntnis der Cladocera und Copepoda des Harzes (mit einer Liste der im Harz gefundenen Oligochaeten-Arten, Anhang 2). Mitteilungen Naturwissenschaftlichen Vereins. Goslar, 7: 219260.

Francisco, P. and Rey, J. 1994. Etude du peuplement zooplanctonique de la retenue de Pareloup. Hydroécologie Appliquée, 6: 175-196.

Foulger, G.R. 2006. Older crust underlies Iceland. Geophysical Journal International, 165: 672-676.

Foulger, G.R. 2010. Plates vs. Plumes: A Geological Controversy. Oxford, Wiley-Blackwell. 364p.

Foulger, G.R. and Anderson, D. L. 2005. A cool model for the Iceland hotspot. Journal of Volcanology and Geothermal Research, 141: 1-22.

Foulger, G.R. and Natland, J. H. 2003. Is 'hotspot' volcanism a consequence of plate tectonics? Science, 300: 921-922.

Garcia-Castellanos, D. and Villaseñor, A. 2011. Messinian salinity crisis regulated by competing tectonics and erosion at the Gibraltar arc. Nature, 480: 359-365.

Garcia-Castellanos, D.; Estrada, F.; Jiménez-Munt, I.; Gorini, C.; Fernàndez, M.; Vergés, J. and De Vicente, R. 2009. Catastrophic flood of the Mediterranean after the Messinian salinity crisis. Nature, 462: 778-781.

Garcia-Gil, L.J.; Borrego, C.M.; Vila, X.; Bañeras, L. and Colomer, J. 1992. Banyoles. Visit to the aquatic ecosystems of Lake Banyoles karstic area. p 1-13. In: J. Catalan and J.L.I. Pretus (eds), Mid-Congress Excursions XXV SIL Congress. Univ. Barcelona, Barcelona.
Garcia-Jurado, F.; Jimenez-Gómez, F. and Guerrero, F. 2011. Effects of a dry period on the limnological characteristics of a Mediterranean high mountain lake. Limnetica, 30: 5-16.

Garcia-Jurado, F.; Vicente, I.; Galotti, A.; Reul, A.; JiménezGómez, F. and Guerrero, F. 2012. Effect of drought conditions on plankton community and on nutrient availability in an oligotrophic high mountain lake. Arctic, Antarctic, and Alpine Research, 44: 50-61.

Gjorgjevic, Z. 1908. Ein Beitrag zur Kenntnis der Diaptomiden Serbiens. Zoologischer Anzeiger, 32: 201-207.

Graeter, E. 1903. Die Copepoden der Umgebung Basel. Revue Suisse de Zoologie, 11: 419-541.

Grainger, J.N. R. 1966. Diaptomus castor in Co. Meath. The Irish Naturalist Journal, 15: 211.

Gruzdev, A.R. 2014. Natural State Reserve "Wrangel Island. Annals of Nature, 2013. Pevek, Ministry of Natural Resources and Environment of the Russian Federation. 74p.

Guerne, J. de and Richard, J. 1889a. Révision des Calanides d'eau douce. Mémoires de la Societé zoologique de France, 2: 53-18.

Guerne, J. de and Richard, J. 1889b. Sur la faune des eaux douces du Groenland. Comptes rendus des séances de l'Académie des Sciences. 108: 630-63.

Guerne, J. and Richard, J. 1892. On the freshwater fauna of Iceland. Annals and Magazine of Natural History, 10: 340-342.

Guisande. C.; Bartumeus, F.; Ventura, M. and Catalan, J. 2003. Role of food partitioning in structuring the zooplankton community in mountain lakes. Oecologia, 136: 627-634.

Gurney, R. 1909. On the freshwater Crustacea of Algeria and Tunisia. Journal of the Royal Microscopical Society, 16: 273-305.

Gurney, R. 1940. Some notes on the biology of the Copepod Diaptomus castor. Annals and Magazine of Natural History, 6: 277-283.

Haberbosch, P. 1920. Die Süsswasser-Entomostraken Grönlands. Eine faunistische, ökologische und tiergeographische Studie. Zeitschrift für Hydrologie, 1(1/2): 136-184, 1(3/4):245-349.

Halbach, U. and Flechtner, G. 1976. Limnologische Untersuchungen im Rahmen des Thjorsarver-Projectes. Verhandlungen der Gesellschaft für Ökologie, 1975, 143-159.

Hamaidi, F.; Defaye, D. and Semroud, R. 2010. Copepoda of Algerian Fresh Waters: Checklist, New Records, and Comments on their Biodiversity. Crustaceana, 83: 101-126.

Hartmann, 0. 1915. Ueber eine lokale Variation und einen neuen Fundort des Diaptomus tatricus Wierz. Zoologischer Anzeiger, 45: 456-460.

Hartwig, W. 1901. Die freilebenden Copepoden der Provinz Brandenburg. Vierter Beitrag. Forschungsberichte aus der Biologischen Station zu Plön, 8: 55-63.

Heads, M.J. 1989. Integrating earth and life sciences in New Zeland natural history: the parallel arcs model. New Zealand Journal of Zoology, 16: 549-585.

Heads, M.J. 2004. What is a node? Journal of Biogeography, 31: $1883-1891$.

Heads, M.J. 2009. Globally basal centres of endemism: the Tasman-Coral Sea region (south-west Pacific), Latin America and Madagascar/South Africa. Biological Journal of the Linnean Society, 96: 222-245. 
Heads, M.J. 2012. Molecular Panbiogeography of the Tropics. Berkeley, University of California Press, 576p.

Hebert, P.D. and Hann, B.J. 1986. Patterns in the composition of arctic tundra pond microcrustacean communities. Canadian Journal of Fisheries and Aquatic Sciences, 43: 1416-1425.

Henderson, I. 1989. Quantitative panbiogeography: an investigation into concepts and methods. New Zealand Journal of Zoology, 16: 495-510.

Herbst, H.-V. 1951. Neue und bemerkenswerte Copepoden (Crustacea) der deutschen Fauna. Zoologischer Anzeiger, 147: 246-254.

Herbst, H.V. 1955. Ein neuer deutscher Calanoide (Crustacea Copepoda) Diaptomus rostripes n. sp. Zoologischer Anzeiger, 155: $248-25$.

Hijmans, R. J.; Guarino, L.; Cruz, M. and Rojas, E. 2001. Computer tools for spatial analysis of plant genetic resources data: 1 . DIVA-GIS. Plant Genetic Resources Newsletter, 127: 15-19.

Illyova, M. and Kubicek, F. 2002. Crustaceans (Crustacea: Cladocera, Copepoda) of the Morava River alluvium on the Slovak territory. Acta Societatis Zoologicae Bohemicae, 66: 205-212.

INYPSA. 2001. Evaluación de la amplitud de usos de zonas húmedas del ámbito territorial del plan hidrológico y I de la confederación hidrográfica del Guadiana: memoria de síntesis, Extremadura. 133p.

Jamieson, C. 1998. Calanoid copepod biogeography in New Zealand. Hydrobiologia, 367: 189-197.

Jenkins, D.G. and Underwood, M.O. 1998. Zooplankton may not disperse readily in wind, rain, or waterfowl. Hydrobiologia, 387/388: 15-21.

Jónasson, I.R. and Malmquist, H.J. 2002. Rannsóknir á Thrihyningsvatn 1998. Institut for Freshwater Fisheries. 20 pp. VMST-R/0202

Jurine, L. 1820. Histoire des Monoculus, qui se trouvent aux environs de Genéve. Genéve, Paris: Paschoud, 258p.

Khodami, S.; McArthur, J. V.; Blanco-Bercial, L. and Arbizu, P.M. 2017. Molecular phylogeny and revision of copepod orders (Crustacea: Copepoda). Scientific Reports, 7: 9164.

Kiefer, F. 1926. Diagnosen neuer Süsswasser-Copepoden aus Afrika. Zoologischer Anzeiger, 66: 262-269.

Kiefer, F. 1928. Beitrag zur Kenntnis der freilebenden Copepoden Marokkos. Bulletin de la Société des Sciences naturelles du Maroc, 8: 87-108.

Kiefer, F. 1938. Zur Kenntnis einiger Diaptomiden (Crust. Cop.) von der Balkanhalbinsel (Bulgarien und Insel Korfu). Zoologischer Anzeiger, 123: 251-25.

Kiefer, F. 1955. Freilebende Ruderfusskrebse (Crustacea Copepoda) aus Binnengewässern Marokkos. Bulletin de la Société des Sciences Naturelles et Physiques du Maroc, 34: 317-336.

Kiefer, F. 1956. Vergleichend-morphologische Untersuchungen an Diaptomus cyaneus Gurney, 1909. Memorie dell' Instituto Italiano di Idrobiologia, 9: 49-60.

Kiefer, F. 1972. Zur Kenntnis von Morphologie und Systematik einiger Arten der Gattung Diaptomus (s. restr.) (Crustacea Copepoda). Zoologica Scripta, 1: 229-240.

Kiefer, F. and Einsle, U. 1963. Vom Litzelsee bei Markelfingen. Beobachtungen an Kleinkrebsen eines periodischen
Frühjahrstümpels. Schriften des Vereins für Geschichte des Bodensees und seiner Umgebung, 81: 1-10.

Klausener, C. 1908. Die Blutseen der Hochalpen. Internationale Revue der gesamten Hydrobiologie und Hydrographie, 1: 359424.

Kortschagin, A. 1887. Fauna Moskovskikh okrestnostei. Rakoobraznyya. Izvestiya Imperatorskavo Obschestva Lubitelyei Yestyestvoznaniya. Antropologii i Etnografii Moscow University, 52: 1-32. (Russian)

Kortschagin, N.A. 1873. Contributions to the knowledge of fauna of the eastern shore of the Black Sea: Copepoda. Zapiski Kiivs'kogo Tovaristva Prirodoznavtsiv, 3: 370-429.

Landsvirkjun. 1976. Pórisvatn, Orkustofnun (National Energy Authority) Report OS - ROD 7643, 35 pp.

Loppens, K. 1908/1909. Contribution a l'étude du micro-plancton des eaux saumatres de la Belgique. Annales de Biologie Lacustre, 3: $16-53$.

Maguire, B., Jr. 1963. The passive dispersal of small aquatic organisms and their colonization of isolated bodies of water. Ecological Monographs, 33: 161-185.

Maillet, G. 2010. Plan de gestion 2010-2019 de la Tourbière du Grand Lemps, $1^{\text {ère }}$ partie: Diagnostic écologique. CEN Isère - AVENIR. 381p.

Malmquist, H.J. 2005. Lífríki Langasjávar: sérkenni og verndargildi (Ecosystem Langisjór: Characteristics and conservation). "Langisjór: Value of natural pearl and imaging plant Conference of the Land Protection. The Nordic House in Reykjavík, Kópavogur Museum of Natural History www. natkop.is: $16 \mathrm{p}$.

Malmquist, H.J.; Olafsson, J.S.; Guðbergsson, G.; Antonsson, T.; Skúlason, S. and Snorrason, S.S. 2003. Vistfrædi - og Verndarflokkun Íslenskra Stöduvata (Ecological and conservational classification of Icelandic lakes. Projects worked for the framework for the utilization of Renewable Energy Resources. Progress report.), Náttúrufræðistofa Kópavogs: 33p.

Malmquist, H.J.; Guðbergsson G.; Jónsson, I.R.; Ólafsson, J.S.; Ingimarsson, F.; Jóhannsdóttir, E.E.; Magnúsdóttir, R.T.; Sigurðardóttir, S.G.; Stefánsson, S.M.; Hansen, Í. and Snorrason, S.S. 2001. Vatnalífríki á virkjanaslóð: Áhrif fyrirhugaðrar Kárahnjúkavirkjunar ásamt Laugarfellsveitu, Bessastaðaárveitu, Jökulsárveitu, Hafursárveitu og Hraunaveitu á vistfræði vatnakerfa. LV-2001/025.

Mann, K. 1940. Ueber pelagische Copepoden türkischer Seen (mit Berücksichtigung des übrigen Planktons). Internationale Revue der gesamten Hydrobiologie und Hydrographie, 40: 1-87.

Marazanof, F. 1963. Cycle annuel des populations de Cladoceres et Copepodes du Saint-Seren, de la Baisse Salee des Relongues et Cerisiferes dc la Tour du Valat. Terre et Vie, 3: 335-356.

Marques, S. C; Azeiteiro, U.M.; Leandro, S.M.; Queiroga, H.; Primo, A.L.; Martinho, F., Viegas, I. and Pardal, M.A. 2008. Predicting zooplankton response to environmental changes in a temperate estuarine ecosystem. Marine Biology, 155: 531-541.

Marrone, F. and Naselli-Flores, L. 2004. First record and morphological features of Hemidiaptomus (Occidodiaptomus) ingens (Gurney, 1909) (Copepoda Calanoida) in Italy. Journal of Limnology, 63: 250-255. 
Marrone, F.; Lo Brutto, S. and Arculeo, M. 2010. Molecular evidence for the presence of cryptic evolutionary lineages in the freshwater copepod genus Hemidiaptomus G.O. Sars, 1903 (Calanoida, Diaptomidae). Hydrobiologia, 644: 115-125.

Marrone, F.; Alfonso, G.; Naselli-Flores, L. and Stoch, F. 2017. Diversity patterns and biogeography of Diaptomidae (Copepoda, Calanoida) in the Western Palearctic. Hydrobiologia, 800: 45-60.

Marrone, F.; Lo Brutto, S.; Hundsdoerfer, A. K. and Arculeo, M. 2013. Overlooked cryptic endemism in copepods: Systematics and natural history of the calanoid subgenus Occidodiaptomus Borutzky 1991 (Copepoda, Calanoida, Diaptomidae). Molecular Phylogenetics and Evolution, 66: 190-202.

Medina-Sánchez, J.M.; Villar-Argaiz, M.; Sánchez-Castillo, P.; Cruz-Pizarro L. and Carrillo, P. 1999. Structure changes in a planktonic food web: biotic and abiotic controls. Journal of Limnology, 58: 213-222.

Menu-Marque, S.; Morrone, J. and Mitrovich, C. 2000. Distributional patterns of the South American species of Boeckella (Copepoda: Centropagidae): a track analysis. Journal of Crustacean Biology, 20: 262-272.

Mercado-Salas, N.; Pozo, C. and Morrone, J.E.S.M. 2012. Distribution patterns of the American species of the freshwater genus Eucyclops (Copepoda: Cyclopoida). Journal of Crustacean Biology, 32: 457-464.

Milad, S. S. 1974. Structure changes in a planktonic food web: biotic and abiotic controls. University of Salford, Ph.D. Thesis. 139 p. [Unpublished].

Miliani, D.; Rybarczyk, H.; Meziane, T. and Eddine, D. S. 2014. Influence of hydrologic regime on zooplanktonic diversity of Harreza Dam (Haut-Cheliff) Ain Defla Algeria. International Journal of Zoology and Research, 4: 35-48.

Miracle, M.R. 1978. Composición especifica de las comunidades zooplanctónicas de los Pirineos y su interés biogeográfico. Oecologia Acuatica, 3: 167-191.

Mjelde, R.; Breivik, A. J.; Raum, T.; Mittelstaedt, E.; Ito, G. and Faleide, J. I. 2008. Magmatic and tectonic evolution of the North Atlantic. Journal of the Geological Society, 165: 31-42.

Mookkaiah, G.J. and Ravichandran, R. 2016. Phylogenetic information of freshwater copepod (Diaptomus sicilis) with special reference to $18 \mathrm{~S}$ rRNA. International Journal of Biological Research, 4: 25-28.

Moreira, J.M. 2005. Caracterización Ambiental de Humedales en Andalucía., Consejería de Medio Ambiente. Junta de Andalucía. 511p.

Morrone, J.J. and Crisci, J.V. 1995. Historical biogeography: introduction to methods. Annual Review of Ecology and Systematics, 26: 373-401.

Mura, G. and Brecciaroli, B. 2003. The zooplankton crustacean of the temporary waterbodies of the Oasis of Palo (Rome, central Italy). Hydrobiologia, 495: 93-102.

Naidenow, W. 1964. Untersuchungen über die Copepoden- und Cladocerenfauna Thrakiens. Die Fauna Bulgariens, 1: 377-404.

Nefedov, A.A. 2013. What reserve could be in Kurumbel Steppe ? Steppe Bulletin, 39: 36-43.

Nevsky, S.S. 2006. The ecological structure of zooplankton of temporary reservoirs of the Saratov area. Saratov State University, Saratov, Russia, Ph.D Thesis. 255p. [Unpublished]
Norman, A.M. and Scott, T. 1906. The Crustacea of Devon and Cornwall. London, 232p.

Norman, A.M. and Brady, G.S. 1909. The Crustacea of Northumberland and Durham. Transactions of the Natural History Society Northumberland, Durham, and Newcastle-OnTyne, 3: 252-417.

Novichkova, A.; Chertoprud, E. and Gislason, G.M. 2014. Freshwater Crustacea (Cladocera, Copepoda) of Iceland: taxonomy, ecology, and biogeography. Polar Biology, 37: 1755-1767. doi:10.1007/s00300-014-1559-x.

Novichkova, A.A. and Chertoprud, E.S. 2015. The freshwater crustaceans (Cladocera: Copepoda) of Bering Island (Commander Islands, Russian Far East): species richness and taxocene structure. Journal of Natural History, 50: 21-22.

Novichkova, A. 2016. The first data on the freshwater microcrustaceans of Shokalsky Island (Russian Arctic). Biodiversity Data Journal, 4: e10930.

Page, R.D.M. 1987. Graphs and generalized tracks: quantifying Croizat's panbiogeography. Systematic Zoology, 36: 1-17.

Parco Nazionale del Gargano, Italy, Puglia. 2012. http: / / www.parcogargano.gov.it/servizi / Menu/dinamica.aspx? id Area $=17308 \&$ idCat $=$ $17308 \& \mathrm{ID}=17308 \&$ TipoElemento=area.

Pesta, O. 1938. Neue Nachweise bemerkenswerter Diaptomiden (Crust. Copepoda). Zoologischer Anzeiger, 121: 150-155.

Pipan, T. 2005. Fauna of the Pivka intermittent lakes. Acta Carsologica, 34: 650-659.

Pirocchi, L. 1947. Diaptomidi d’Alta Montagna III. II Diaptomide di Peirafica (Alpi maritime). Memori dell'Istituto Italiano di Idrobiologia, 3: 467-476.

Poppe, S.A. 1889. Notizen zur Fauna der Süsswasser-Becken des nordwestlichen Deutschland mit besonderer Berücksichtigung der Crustaceen. Abhandlungen des Naturwissenchaftlichen Vereins Bremen, 10: 517-551.

Preston, C.D.; Bratton, J.H. and Coombe, D.E. 1989. The ephemeral pools of south Cambridgeshire. Nature in Cambridgeshire, 31: 2-11.

Rabet, N. 1999. Observations carcinologiques (Branchiopoda: Anostraca, Notostraca; Copepoda: Calanoida) dans les garrigues septentrionales du Gard (France). Bulletin de la Société d'étude des sciences naturelles de Nîmes, 62: 70-74.

Rabet, N.; Cart, J.-F.; Montero, D. and Boulekbache, H. 2005. First record of Lynceus brachyurus Müller, 1776 (Branchiopoda, Laevicaudata, Lynceidae) in France. Crustaceana, 78: 931940.

Ramdani, M. 1986. Ecologie des Crustacés (Copépodes, Cladocères et Ostracodes) des mares temporaires (Dayas) Marocaines. Faculté des Sciences du Saint-Charles, Université de Provence. Ph.D. Thesis. 218p [Unpublished].

Ramdani, M.; Champeau, A. and Pont, D. 1989. Le genre Diaptomus (Copepodes, Diaptomides) au Maroc. Bulletin de l'Institut scientifique, 13: 99-104.

Ramdani, M.; Elkhiati, N.; Flower, R.J.; Birks, H.H.; Kraïem, M.M.; Fahti, A.A. and Patrick, S.T. 2001. Open water zooplankton communities in North African wetland lakes: the CASSARINA Project. Aquatic Ecology, 35: 319-333.

Reed, E.B. 1962. Freshwater plankton crustacea of the Colville River area, northern Alaska. Arctic, 15: 27-50. 
Reynolds, J.D. and Marnell, F. 1999. New records of Eurycercus glacialis (Cladocera: Chydoridae) in Turloughs in South-East Galway. The Irish Naturalists' Journal, 26: 177-180.

Riserva Natural Capo Gallo, Italy, Sicily. Available at http://www. palermoweb.com/cittadelsole/vtour/riserve/. Accessed on 24 April 2015.

Röben, P. 1970. Zur Crustaceenfauna (freilebende Cyclopoida, Calanoida und Cladocera) der Heidelberger Umgebung. Beiträge zur naturkundlichen Forschung in Südwestdeutschland, 29: 115-146.

Roy, J. 1922. Sur les Copépodes libres de la Cote-d'Or. Bulletin de la Société Zoologique de France, 47: 186-191.

Roy, J. 1927. Liste préliminaire des Copépodes recueillis dans les eaux douces du Département de la Sarthe. Bulletin de la Société Zoologique de France, 52: 163-166.

Roy, J. 1931. Copépodes et Cladocères de la region Pyrénéenne. Bulletin de la Société Zoologique de France, 56: 542-546.

Rundle, S.D.; Foggo, A.; Choiseul, V. and Bilton, D.T. 2002. Are distribution patterns linked to dispersal mechanism? An investigation using pond invertebrate assemblages. Freshwater Biology, 47: 1571-1581.

Sahuquillo, M. and Miracle, M.R. 2010. Crustacean and rotifer seasonality in a mediterranean temporary pond with high biodiversity (Lavajo de Abajo de Sinarcas, Eastern Spain). Limnetica, 29: 75-92.

Samchyshyna, L.V. 2005. Ecological and faunistic and morphological aspects of freshwater and brackish Research on Calanoida (Crustacea Copepoda) of Ukraine. Inst. Zool. II Schmalhausen. Kiev. Candidate of biological sciences: 211p.

Samraoui, B. 2002. Branchiopoda (Ctenopoda and Anomopoda) and Copepoda from eastern Numidia, Algeria. Hydrobiologia, 470: 173-179.

Schauß, R. 1911. Zur Entomostraken-Fauna des NiederrheinGebietes, p. 22-23. In: Berichte über die Versammlungen des Botanischen und des Zoologischen Vereins für RheinlandWestfalen.

Scher, O.; Defaye, D.; Korovchinsky, N.M. and Thiéry, A. 2000. The crustacean fauna. (Branchiopoda, Copepoda) of shallow freshwater bodies in Iceland. Vestnik Zoologii, 34: 11-25

Scott, T. 1892. Diaptomus castor Jurine, in the Braid ponds near Edinburgh. The Annals of Scottish Natural History, 1: 202-203.

Scott, T. 1902. Notes on fresh and brackish-water Entomostraca found in Aberdeenshire. The Annals of Scottish Natural History, 11: 21-29.

Scott, T. 1906. A catalogue of land, fresh-water, and marine Crustacea found in the basin of the River Forth and its estuary. Part I - Malacostraca, Cladocera, and Branchiura. Part II. The Ostracoda, Copepoda, and Cirripedia. Proceedings of the Royal Physical Society of Edinburgh, 16: 37-386.

Selden, P.A.; Huys, R.; Stephenson, M.H.; Heward, A.P. and Taylor, P.N. 2010. Crustaceans from bitumen clast in Carboniferous glacial diamictite extend fossil record of copepods. Nature Communications, 1: 50.

Semyonova, L.A. and Aleksyuk, V.A. 2010. Zooplankton of the lower Ob River. Journal of Ecology, Forest and Landscape, 10: 156-169.
Serrano, L. and Fahd, K. 2005. Zooplankton communities across a hydroperiod gradient of temporary ponds in the Doñana National Park (SW Spain). Wetlands, 25: 101-111.

Siewerth, M.W. 1927. Obzor fauny presnovodnykh Eucopepoda Ukrainy. Review of the freshwater Eucopepoda fauna of the Ukraine. Trudy Kharkovskogo obstchestva ispytatelej prirody, 50: 121-140. (Russian).

Sivakumar, K.; Archana, K.; Shree Rama, M.; Muthupriya, P. and Altaff, K. 2016. Phylogenetic analysis of $18 \mathrm{~S}$ rDNA of freshwater copepods Neodiaptomus species and Mesocyclops species. Journal of Advanced Zoology, 37: 64-74.

Smirnov, S.S. 1929. Beiträge zur Eucopepodenfauna Mittelrusslands. Arbeiten biologie Stn. Kostroma, 1: 1-12.

Smyly, W.J.P. 1958. The Cladocera and Copepoda (Crustacea) of the Tarns of the English Lake District. Journal of Animal Ecology, 27: 87-103.

Stella, E. 1964. Diaptomidi (Crustacea, Copepoda, Calanoida) di pozze temporanee del Lazio. Rivista di Biologia, 57: 237-259.

Stella, E. and Margaritora, F. 1968. La fauna ad entomostraci di acque astatiche del Lazio: ricerche ecologiche e biologiche. Rendiconti Accademia Nazionale dei XL, Serie IV, 22: 1-59.

Stella, E., Margaritora, F.G. and Cottarelli, V. 1972. La fauna ad entomostraci di acque astatiche della Sardegna nord orientale: ricerche biologiche ed ecologiche. Rendiconti Accademia Nazionale del XL, Serie IV, 22: 1-50.

Stepanova, L.A. 2008. Species of the genus Diaptomus (Crustacea, Diaptomidae) in the Siberian fauna. Zoologičeskij žurnal, 87: 912-922.

Stephensen, K. 1917. III. Zoogeographical investigations in southern Greenland, with special reference to Crustacea, Pycnogonida and Echinodermata. Including a list of Alcyonaria and pisces. Meddelser om Grønland, 53: 230-378.

Stross, R.G.; Miller, M.C., and Daley, R.J. 1980. Zooplankton. p. 251-296. In: J. E. Hobbie (ed), Limnology of tundra ponds, Barrow, Alaska. Stroudsburg, Pennsylvania, Dowden, Hutchinson and Ross, Inc.

Sukop, I. 2008. Temporary periodical pools of the lower reaches of the Dyje (Thaya) River. Acta universitatis agriculturae et silviculturae Mendelianae Brunensis, 56: 181-188. (Czech).

Tash, J.C. 1971. The zooplankton of fresh and brackish waters of the Cape Thompson area, northern Alaska. Hydrobiologia, 38: 93-121.

Tash, J.C. and Armitage, K.B. 1967. Ecology of zooplankton of the Cape Thompson area, Alaska. Ecology, 48: 129-139.

Thum, R.A. 2004. Using 18S rDNA to resolve diaptomid copepod (Copepoda: Calanoida: Diaptomidae) phylogeny: an example with the North American genera. Hydrobiologia, 519: 135141.

Torsvik, T.H.; Amundsen, H.E.F.; Tronnes, R.G.; Doubrovine, P.V.; Gaina, C.; Kusznir, N.J.; Steinberger, B.; Corfu, F.; Ashwal, L.D.; Griffin, W.L.; Werner, S.C. and Jamtveit, B. 2015. Continental crust beneath southeast Iceland. Proceedings of the National Academy of Sciences, USA, 112: E1818-E1827.

Traykov, I.; Boyanovsky, B. and Zivkov, M. 2011. Composition and abundance of zooplankton in Kardzhaly Reservoir. Bulgarian Journal of Agricultural Science, 17: 501-511. 
Van Breemen, P.J. 1908. Vrijlevende zoetwater-copepoden van Nederland. Tijdschrift der Nederlandsche Dierkundige Vereeniging, $2^{\text {nd }}$ Serie, 10: 303-368.

Vega, J.C.; de Hoyos, C. and Aldasoro, J.J. 1992. The Sanabria Lake, the largest natural freshwater lake in Spain. Limnetica, 8: 49-57.

Ventura, M. 2004. Crustacean zooplankton dynamics in Lake Redon: a stoichiometric, biochemical and isotopic approach. Dep. Ecol. Barcelona, Univ. Barcelona. Ph.D. Thesis. 159p. [Unpublished].

Vinarski, M.V.; Palatov, D.M. and Novichkova, A.A. 2015. The first freshwater molluscs from Wrangel Island, Arctic Russia. Polar Research, 34: 23889.

Vizer, L.S.; Prusevich, L.S. and Naumkina, D.I. 2013. Food supply of small of small lakes in Novosibirsk region. Vestnik Nsau, 2: 53-58.
Wawrik, F. 1966. Die Waldviertler Fischteiche und ihre Entomostrakenfauna auf ökologischer Grundlage. Hydrobiologia, 28: 385-552.

Winder, M.; Monaghan, M.T. and Spaak, P. 2001. Have human impacts changed alpine zooplankton diversity over the past 100 years? Arctic, Antarctic, and Alpine Research, 33: 467-475.

Wolf, E. 1903. Dauereier und Ruhezustände bei Kopepoden. Zoologischer Anzeiger, 27: 98-108.

Wolf, E. 1905. Die Fortpflanzungsverhältnisse unserer einheimischen Copepoden. Zoologische Jahrbücher. Abteilung für Systematik, Geographie und Biologie der Tiere, 22: 101-280.

Yevdokimov, N.A. and Yermokhin, M.V. 2009. Zooplankton Crustaceans of Ephemeral Waterbodies on the Territory of Various Natural Zones in Saratov Oblast. Inland Water Biology, 2: 59-66.

Zykoff, W. 1905. Zur Crustaceenfauna der Insel Kolgujev. Zoologischer Anzeiger, 28: 337-345. 